\title{
Conservation Strategy for Silene spaldingii (Spalding's catchfly) in Montana
}

\author{
Prepared for: \\ U.S. Fish and Wildlife Service \\ By: \\ Scott Mincemoyer \\ Montana Natural Heritage Program \\ Natural Resource Information System \\ Montana State Library
}

September 2005

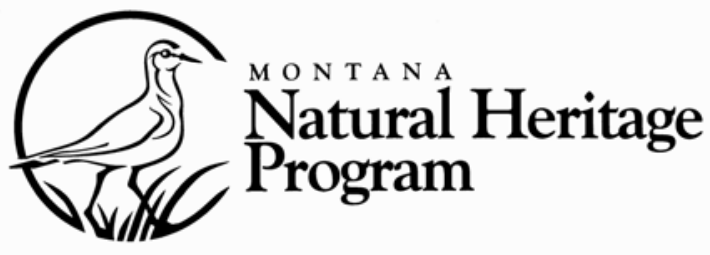




\section{Conservation Strategy for Silene spaldingii (Spalding's catchfly) in Montana}

Prepared for:

U.S. Fish and Wildlife Service

Grant Agreement:

E-5-R-13

By:

Scott Mincemoyer
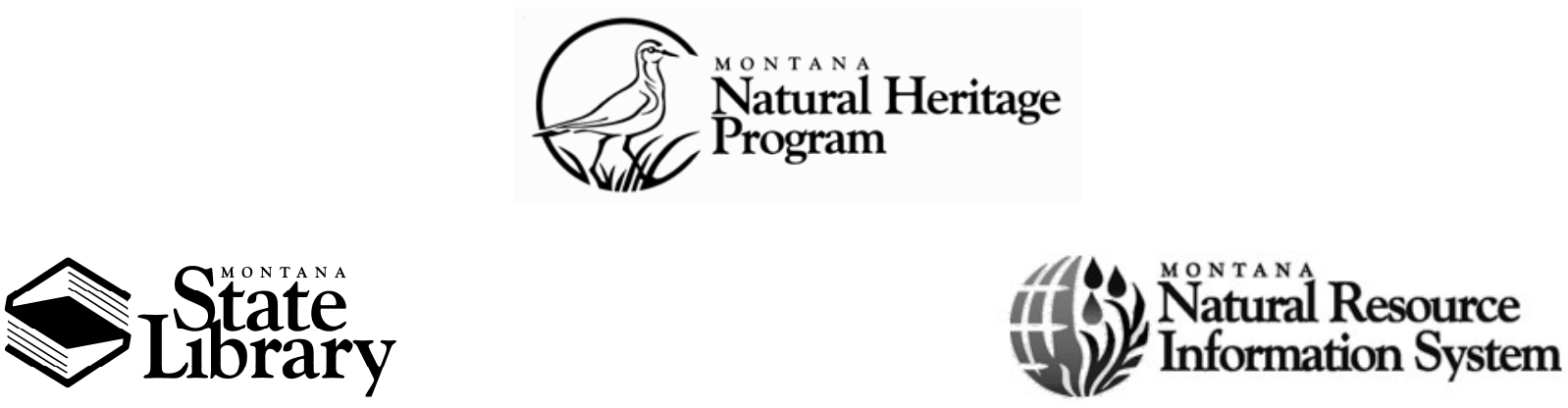

(C) 2005 Montana Natural Heritage Program

P.O. Box 201800 • 1515 East Sixth Avenue • Helena, MT 59620-1800 • 406-444-5354 
This document should be cited as follows:

Mincemoyer, S. 2005. Conservation strategy for Silene spaldingii (Spalding's catchfly) in Montana. Report to the U.S. Fish and Wildlife Service. Montana Natural Heritage Program, Helena, MT. 39 pp. + appendices. 


\section{EXECUTIVE SUMMARY}

Silene spaldingii S. Wats. (Spalding's catchfly) is a perennial forb restricted to Palouse prairie grasslands in eastern Oregon and Washington, adjacent Idaho, and northwest Montana and adjacent British Columbia. Federal protection of the species as "threatened" under the Endangered Species Act was implemented in 2001 (USFWS 2001).

Montana contains a substantial part of the distribution and a large percentage of the total number of $S$. spaldingii plants range-wide. Current estimates of the number of $S$. spaldingii plants in Montana range from 12,000 to 43,000 individuals. Recent data and surveys suggest that Montana probably has 11 extant occurrences, though several are small and threatened by weeds, grazing and development. The 2004 and 2005 field seasons provided important additional information on the distribution and abundance of $S$. spaldingii in northwest Montana.
The purpose of this report is to provide information and strategies important to the management and long-term viability of $S$. spaldingii in Montana, as well as an update on the status of the species. Information on the biology, ecology, distribution, threats, population dynamics and trends specific to the species in Montana is presented. The conservation strategy focuses on several main areas: protecting existing sites, improving habitat condition, rebuilding populations, mitigating impacts of invasive weeds and grazing, and increasing monitoring and survey efforts. Additional studies on site-specific pollinators in Montana, and the genetics of $S$. spaldingii within Montana and range-wide are also needed. Implementation of conservation measures and maintenance of populations within all four geographic locations (Tobacco Valley, Lost Trail area, Niarada area and Wild Horse Island ) are vital to the survival and viability of the species in the state. 


\section{ACKNOWLEDGEMENTS}

This statewide conservation strategy was prepared under a grant from the U.S. Fish and Wildlife Service. Survey data from numerous individuals and staff at the Montana Natural Heritage Program over many years made this assessment possible. Data collected and provided by Peter Lesica were instrumental in completing this assessment. Thanks to the
Confederated Salish and Kootenai Tribe, especially Joanne Bigcrane and Dale Becker, for granting access to reservation lands and providing other help along the way. Thanks to Kathy Lloyd and Tina Laidlaw for editing and proof-reading this report and Coburn Currier for final printing, though any mistakes or errors are of my own doing. 


\section{TABLE OF CONTENTS}

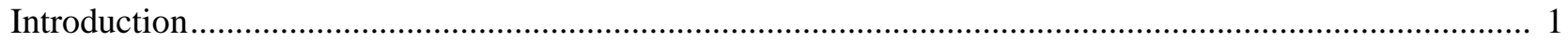

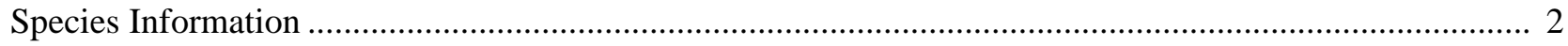

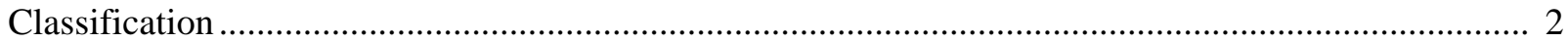

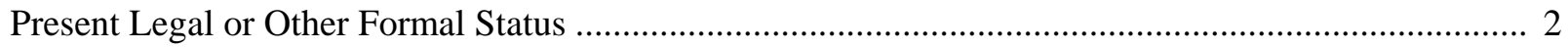

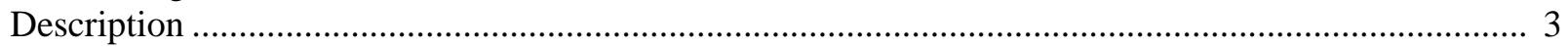

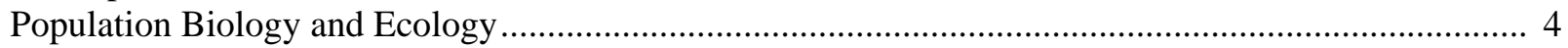

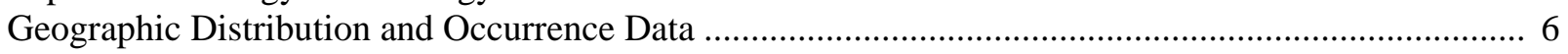

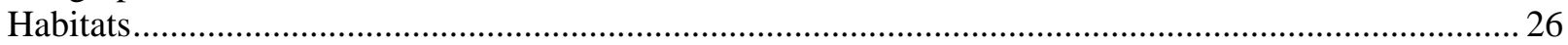

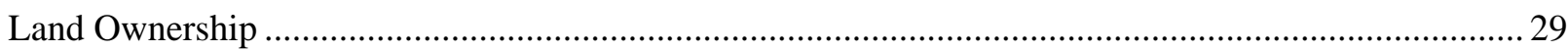

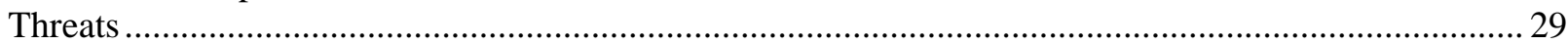

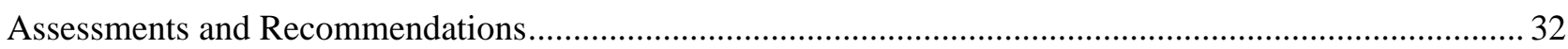

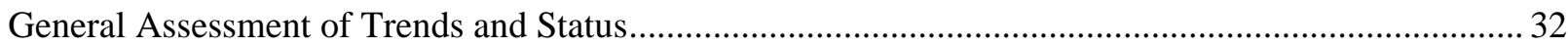

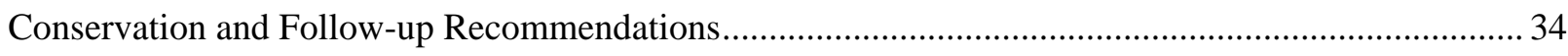

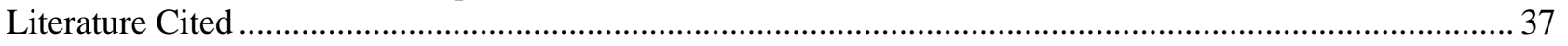

Appendix A. Global/State Rank Definitions

Appendix B. Element Occurrence Rank Definitions

\section{LIST OF FigURES}

Figure 1. State and provincial status of Silene spaldingii (NatureServe 2005) ................................... 2

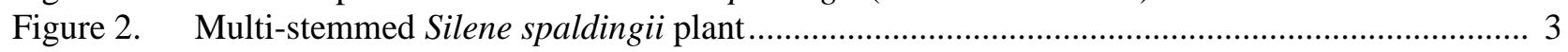

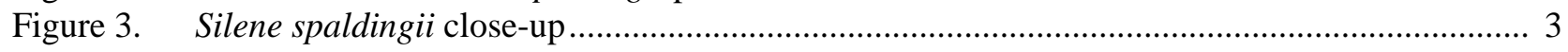

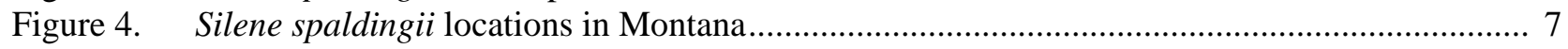

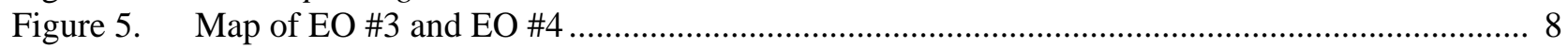

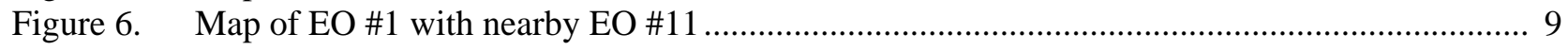

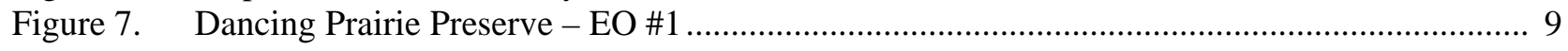

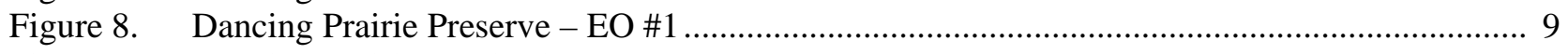

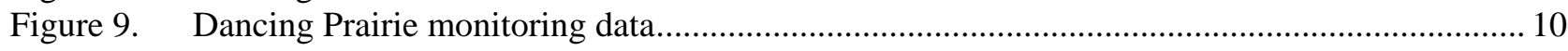

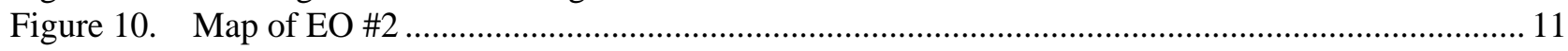

Figure 11. Wild Horse Island - EO \#2, subpopulation A ............................................................... 11

Figure 12. Wild Horse Island - EO \#2, subpopulation B ............................................................... 11

Figure 13. Wild Horse Island monitoring data............................................................................... 12

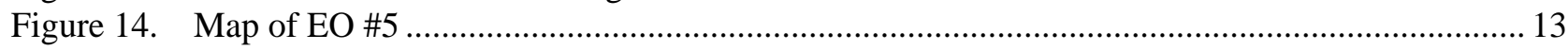

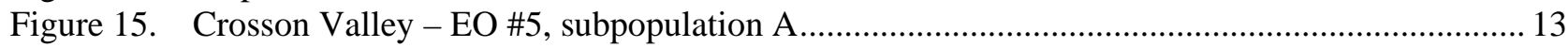

Figure 16. Crosson Valley - EO \#5, subpopulation A..................................................................... 13

Figure 17. Crosson Valley - EO \#5, subpopulation F ….................................................................... 13

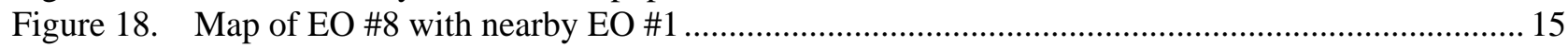

Figure 19. Roosville - EO \#8, subpopulation 3 ............................................................................... 15

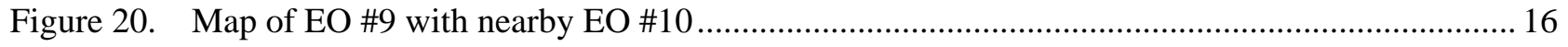

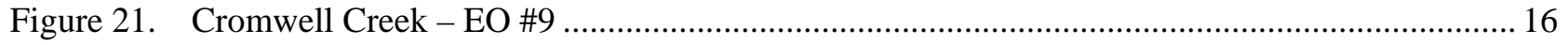

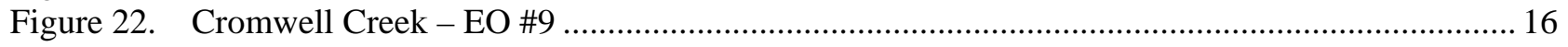

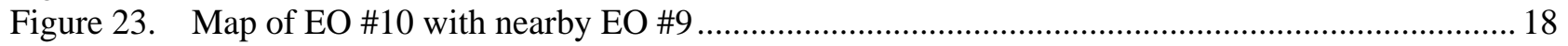

Figure 24. Hog Heaven Range - EO \#10, subpopulation A............................................................... 18

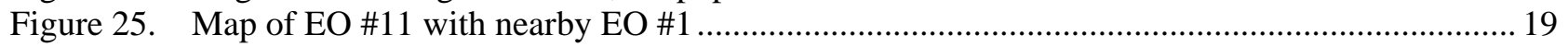

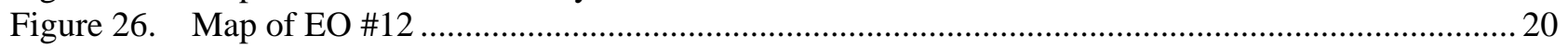

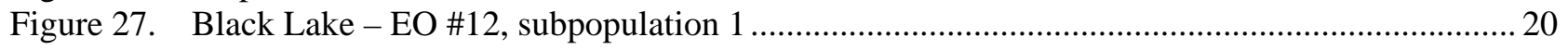

Figure 28. Map of EO \#13 with nearby EO \#14 …............................................................................. 21 
Figure 29. Lost Trail NWR East - EO \#13, subpopulation 2 ........................................................ 21

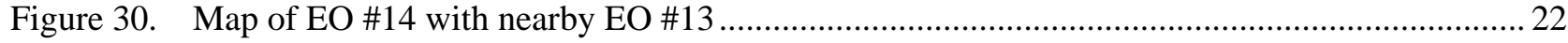

Figure 31. Lost Trail NWR West- EO \#14, subpopulation 1 …........................................................... 22

Figure 32. Lost Trail NWR West- EO \#14, subpopulation 1 …......................................................... 22

Figure 33. $\quad$ Map of EO \#15 with part of nearby EO \#5 ..................................................................... 24

Figure 34. Sullivan Creek - EO \#15, subpopulation 1 .................................................................... 24

Figure 35. Results of predictive habitat modeling for Silene spaldingii using geology, STATSGO soils, annual precipitation and vegetation (NLCD) data layers........................................................ 28

\section{LIST OF TABLES}

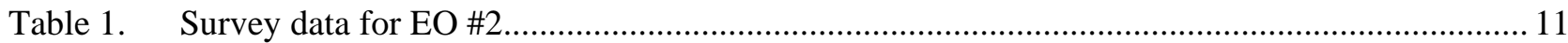

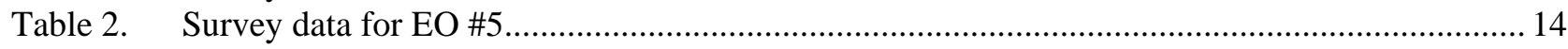

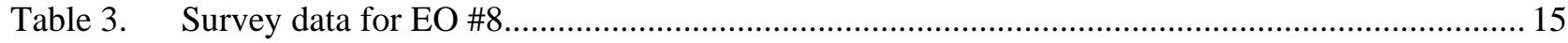

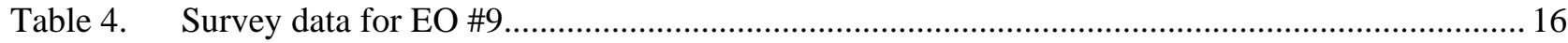

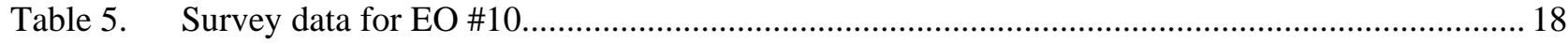

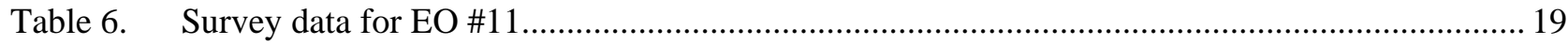

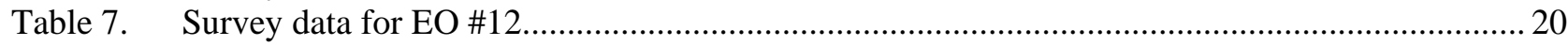

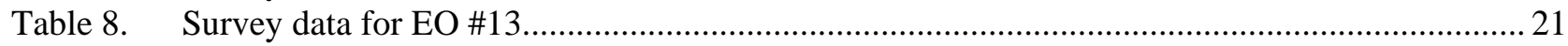

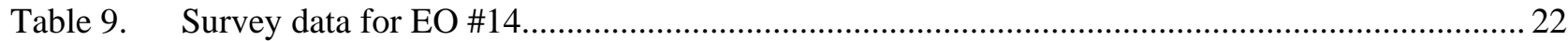

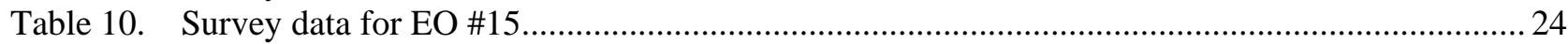

Table 11. Ownership of S. spaldingii by EO rank, excluding historical occurrences............................... 29

Table 12. Estimates of Montana S. spaldingii population size at each occurrence and statewide............... 33

Table 13. Ranking factors and assigned scores for the S. spaldingii Montana status assessment ............... 33 


\section{INTRODUCTION}

Silene spaldingii S. Wats. (Spalding's catchfly) is a perennial forb restricted to Palouse prairie grasslands in eastern Oregon and Washington, adjacent Idaho, and northwest Montana and adjacent British Columbia. Federal protection of the species as "threatened" under the Endangered Species Act was implemented in 2001 (USFWS 2001). Prior to this designation, the species was included on a list of plants considered to be endangered, threatened or extinct in the United States. This list was prepared by the Secretary of the Smithsonian Institution and presented to Congress in 1975 as required by the Act (USFWS 1999). Due to insufficient information, the status of $S$. spaldingii remained undetermined until a petition for listing was received in 1995 and a final determination of threatened was made in 2001 (USFWS 2001).

The purpose of this report is to provide information and strategies important to the management and long-term viability of $S$. spaldingii in Montana and by default across the range of the species. Montana contains a substantial part of the distribution of the species and a large percentage of the total number of plants range-wide. This report presents information on the biology, ecology, distribution, threats, population dynamics and trends specific to the species in Montana. In 2004, a range-wide conservation strategy for the species was produced (Hill and Gray 2004). The 2004 report provides a comprehensive summary of many of the same topics across all occurrences and is a good reference for a more detailed discussion about the habitats, weed dynamics and additional threats to the species. Unfortunately, much of the information the 2004 report contains about Montana populations is already out-of-date due to surveys conducted in 2004 and 2005.
The 2004 and 2005 field seasons provided important additional information on the distribution and abundance of $S$. spaldingii in northwest Montana. Finally, strategies and recommendations for further management, research, and conservation activities are presented that will hopefully help ensure the long-term viability of $S$. spaldingii populations in Montana.

The terms "population" and "occurrence" are generally used interchangeably in this report when referring to sites in Montana. It is recognized that in other reports this may not be the case and that each may have a specific meaning when used elsewhere.

Most of the information contained herein, if not otherwise referenced, is taken directly from Montana Natural Heritage Program data or are field observations by the author.

Taxonomic nomenclature in this report follows the more conservative and traditional treatments of Vascular Plants of Montana (Dorn 1984), since these names are still in common usage and are more widely known among many natural resource professionals. In contrast, many names used in newer references, such as the USDA NRCS PLANTS database (2005), are not yet in wide use outside of the botanical community and some names still appear to be in a possible state of flux, such as the grass tribes Stipeae (needlegrasses) and Triticeae (wheatgrasses), and the species rough fescue (Festuca scabrella) and spotted knapweed (Centaurea maculosa). 


\section{SPECIES INFORMATION}

\section{A. Classification}

1. Scientific Name: Silene spaldingii S. Wats.

2. Common Name: Spalding's catchfly, Spalding's campion

3. Family: Caryophyllaceae (pink family)

4. Type Description: Watson, Serano. 1875. Proceedings of the American Academy of Arts and Sciences. 10:333-350.

5. Size of Genus: In Montana, the genus Silene is represented by 14 species (Dorn 1984).

\section{B. Present Legal and Conservation Status}

1. Global: G2. Ranked on April 2, 1990. Last rank review on March 18, 2003 (NatureServe 2005).

\section{National:}

a. U.S.A.: S. spaldingii was petitioned for listing under the ESA in February 1995 and was listed as a threatened species on October 10, 2001 (U.S. Fish and Wildlife Service 1998, 1999, 2000, 2001).

b. Canada: Committee on the Status of Endangered Wildlife in Canada (COSEWIC): Endangered, May 1, 2005 (NatureServe 2005).

3. State and Provincial: Heritage ranks provided in Figure 1.

Figure 1. State and provincial status of Silene spaldingii (NatureServe 2005).

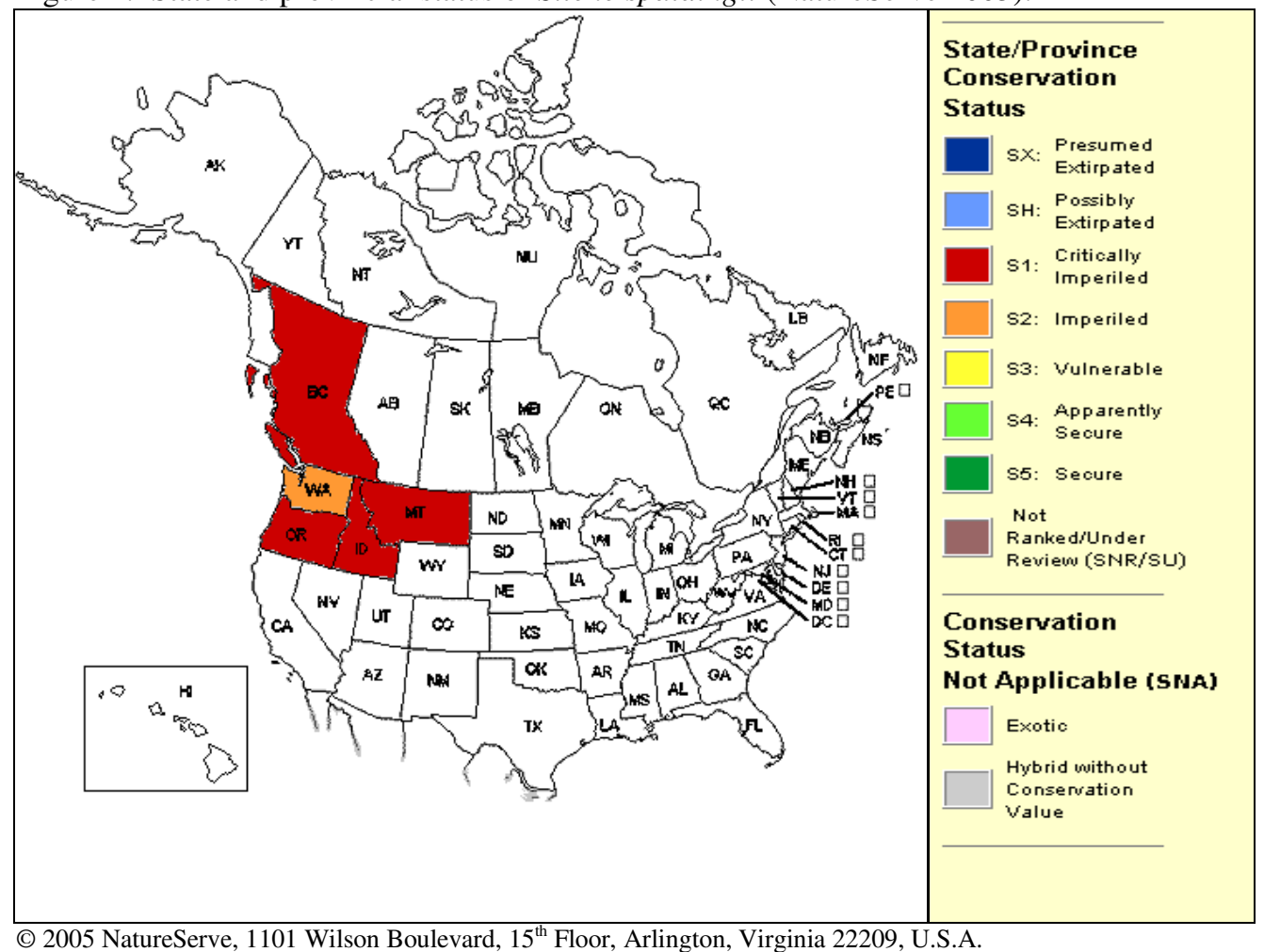




\section{Description}

1. General Non-technical Description:

Spalding's catchfly is a perennial with a simple or branched rootcrown. There are 4-7 pairs of sessile, broadly lance-shaped leaves that are 6-7 $\mathrm{cm}$ long below and gradually reduced in size upward. Herbage is long-hairy and very sticky. There are few to many flowers in a leafy, somewhat open inflorescence. The tubular calyx is about $15 \mathrm{~mm}$ long, has 10 nerves on its surface, and is very sticky. The corolla has 5 separate, white petals, each composed of a narrow claw that is about 15 $\mathrm{mm}$ long expanding into a broadened blade above. Only the entire or shallowly-lobed blade with 4 tiny wings at the base protrudes beyond the mouth of the calyx. The fruit is a capsule that is $10-15 \mathrm{~mm}$ long and filled with numerous tiny seeds.

August 22, 2005

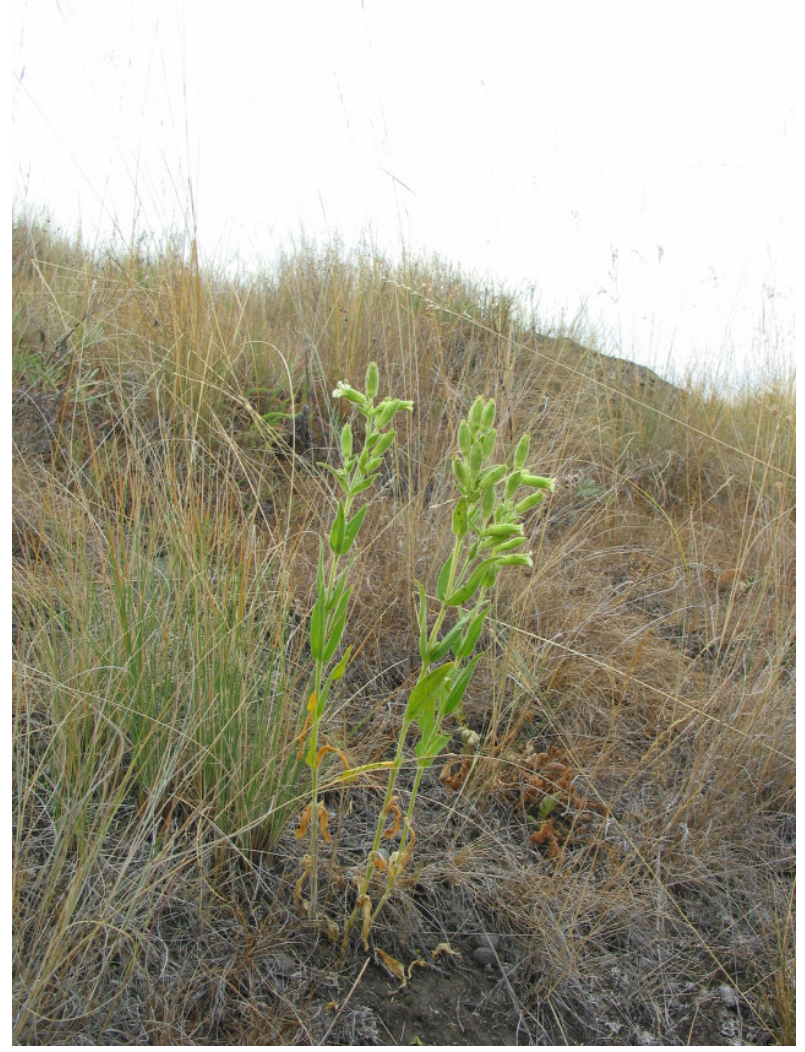

Figure 2. Multi-stemmed Silene spaldingii plant.

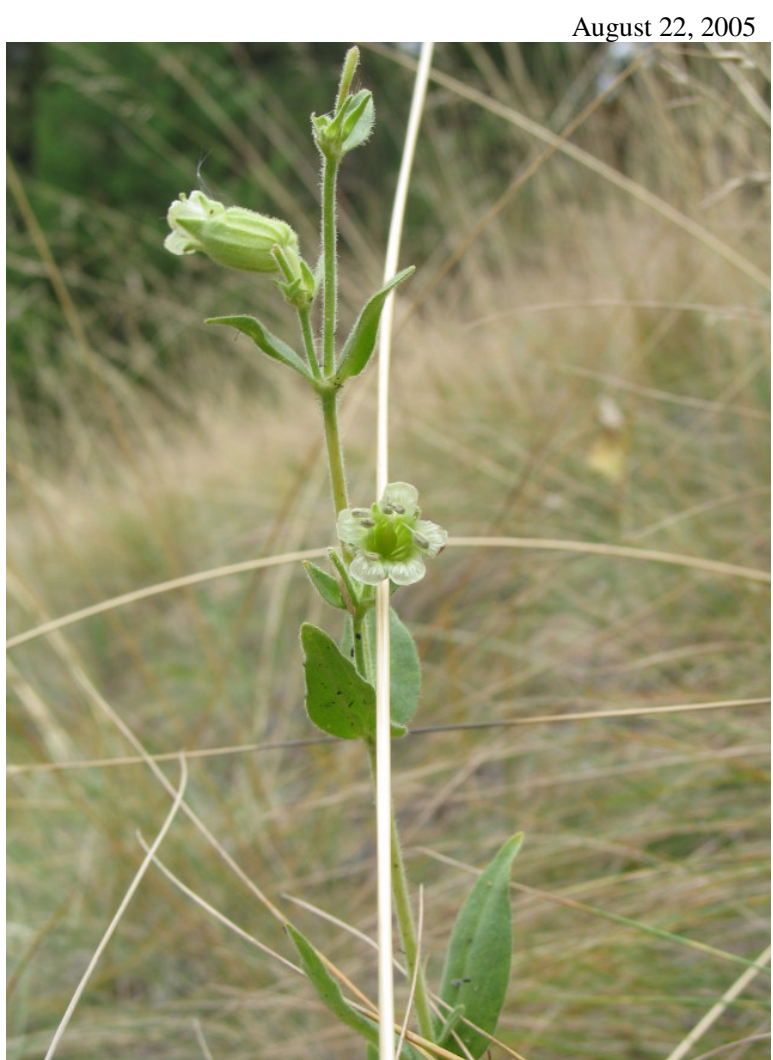

Figure 3. Silene spaldingii close-up.

2. Technical Description: Villous-tomentose and more or less viscid-pubescent perennial from a simple or branched caudex, 2-6 dm tall; cauline leaves 4-7 pairs, oblanceolate below to lanceolate above, $6-7 \mathrm{~cm}$ long, $0.5-1.5 \mathrm{~cm}$ broad, sessile and slightly connate; flowers several to many in a leafy and usually compact cyme; calyx tubularcampanulate, about $15 \mathrm{~mm}$ long at anthesis, becoming more nearly clavate-campanulate in fruit, 10-nerved; corolla white, the claw of the petals about $15 \mathrm{~mm}$ long, not auriculate above, the blade very short, ovate, about $2 \mathrm{~mm}$ long, entire to shallowly emarginate; appendages 4 ( 5 or 6 ), ovate-lanceolate, about $0.5 \mathrm{~mm}$ long; carpophore about $2 \mathrm{~mm}$ long, glabrous; styles 3; capsule 1celled; seeds light brown, about $2 \mathrm{~mm}$ long, corrugate-wrinkled and inflated. Chromosome number $2 \mathrm{~N}=24$ (adapted from Hitchcock et al. 1964).

3. Similar Species: In Montana, both Silene douglasii and S. scouleri occur in northwest Montana in similar habitats. Both species can be distinguished from $S$. spaldingii in their longer $(>2$ 
$\mathrm{mm})$, deeply lobed petal blades when in flower. In contrast, $S$. spaldingii petals are typically 1-2 mm long and entire to shallowly emarginate. Vegetatively, the lower leaves of S. scouleri are longer and the remaining leaves are strongly reduced upward. In $S$. spaldingii, the lower to middle leaves are shorter and broadly lanceolate and only weakly reduced upwards. S. douglasii typically has multiple stems that are more slender than $S$. spaldingii. Also, it is rarely stickypubescent and possesses stems that tend to be decumbent. Other Silene species look superficially similar to $S$. spaldingii and grow in the same habitat though they are easily separated using a technical key and descriptions (Hitchcock et al. 1964).

\section{Population Biology and Ecology}

1. Reproductive Biology and Phenology: Silene spaldingii is a perennial herb capable of living at least five years (Lesica 1997) and is dependent solely on reproduction from seed. Flowers are perfect and protandrous (anthers mature, dehisce pollen and wither before the styles expand and stigmas become receptive) (Lesica 1993). This reproductive strategy limits, though does not exclude, self-pollination. Seeds apparently germinate in the spring and continue to grow while soil moisture is adequate and temperatures are moderate. Plants have been observed as early as May 22 at Dancing Prairie (Lesica 1997). Above ground parts of the seedling plants/rosettes dry up and are senescent during the hottest, driest parts of the summer. Plants may then revive with the onset of cool, moist weather in the fall (Lesica 1988). Flowering may take place during or after the second year with flowers developing in July and August. Each open flower persists for two or more days, and several flowers may be in bloom on the same plant allowing for pollination to occur from flowers on the same plant (geitonogamy). Individual plants flower for 2-3 weeks. Fruits of dehiscent capsules contain up to 150 seeds and mature primarily in August (Lesica 1993). Seeds require a short cold treatment for effective germination and may germinate in the fall as well as the spring following as little as four weeks of cold treatment (Lesica 1993, 1999).
The pollination biology of $S$. spaldingii has been studied by Lesica (1993) and Lesica and Heidel (1996). In Montana, the only pollinators observed visiting $S$. spaldingii plants were bumblebees (Bombus fervidus). Studies of S. spaldingii pollinators in Montana are limited to the Dancing Prairie population. As noted earlier, selfpollination is possible, though Lesica's study (1993) showed very high levels of reduced fitness for progeny of close-pollinated flowers (bagged plants) versus open-pollinated flowers.

2. Species Ecology: Silene spaldingii occupies mesic sites within Palouse grasslands. Generally, plants are found on northerly aspects, in swales or along small draws where it is presumed more moisture remains available during the hot, dry summer months of July and August. S. spaldingii is atypical in that it flowers in July and August in a habitat when most other species have already completed flowering for the season. One potential advantage of this strategy is that it is not competing for pollinators. However, precipitation is usually scarce during this time period resulting in unfavorable soil moisture conditions for plant growth. Potentially in response to these dry conditions, $S$. spaldingii plants may remain dormant in some years. It is unclear if this dormancy is a response to the reduced moisture availability in the previous year, dry conditions during part of the current growing season, some combination of these or to some other factor (Lesica 1999, Lesica and Steele 1994). To date, a correlation between precipitation patterns and dormancy has not been made, though plants do apparently show a strong biennial periodicity (Lesica 1997). On-going demographic monitoring conducted by Lesica should help provide answers.

At Dancing Prairie, Lesica (1997) found that an average of $41 \%$ of $S$. spaldingii plants between 1989 and 1994 exhibited annual dormancy and that dormancy rates ranged from $11 \%$ in 1989 to $74 \%$ in 1994 . Dormancy lasted one year in $75 \%$ of the observed episodes and no more than two years in $90 \%$ of the cases. The study also found that plants spent nearly half their summers in a dormant condition during the six year period.

Growth and recruitment data suggest that new plant establishment is apparently sporadic, though the 
cause is unknown. In Festuca scabrella grasslands, disturbance events such as fire or grazing that reduce litter and thatch build-up may play a role in the establishment and growth of $S$. spaldingii (Lesica 1997, 1999). Menges and Dolan (1998) showed a positive response to fire in the related prairie species Silene regia. Prescribed fires were conducted at Dancing Prairie Preserve in the fall of 1991 and the spring of 1992 and postfire tracking conducted through 1996 show a favorable response to fire. Recruitment of new individuals was significantly higher on spring and fall burned plots compared to recruitment in controls for three years following fire (Lesica 1999). Fire also decreased dormancy rates for the year following fire, but did not have a prolonged effect except to apparently change the biennial cycle of dormancy observed previously at the Preserve. An increase in the number of flowers per plant was also observed in the burn treatments though it is uncertain if this had a long-term beneficial impact. S. spaldingii's positive response to burning is not surprising considering that the valley grasslands it occupies in western Montana may have historically burned on average every 6-9 years (Dorey 1979, Barrett and Arno 1982). Fire, or other disturbance such as grazing, appears to be necessary for reducing litter build-up and for decreasing competition from the dominant bunchgrass in these systems, $F$. scabrella (Lesica 1999). However, grazing is not believed to have been an important historical disturbance or to have played a major role in the development of intermontane grasslands (Mack and Thompson 1982).

3. Genetics: A genetics study was conducted in 1994 by Baldwin and Brunsfeld (1995) to elucidate the distribution of genetic variation within and among populations. Enzyme electrophoresis was performed on 96 individuals from five populations: one in Idaho and one in Oregon, both from the Hells Canyon area, two from Washington, and one from the Dancing Prairie population in Montana. Results of this small analysis indicated the existence of two genetically distinct subpopulations; a northern subpopulation consisting of the Lamona, Washington population and the Dancing Prairie population, and a southern population consisting of the three remaining occurrences. Also, populations from Hells Canyon are very similar based on an analysis of Nei (1978) unbiased genetic distance (.000). Additional work, using restriction site analysis of cpDNA, revealed a length mutation in the Lamona population and possibly the Dancing Prairie population, providing further evidence of distinct northerly and southerly populations. Levels of genetic diversity observed by this study are comparable to levels observed by other studies of rare Silene species: Silene regia in the Midwest (Dolan 1994) and Silene hawaiiensis on the Hawaiian Islands (Westerbergh and Saura 1994).

The Dancing Prairie population was the only one to show a higher frequency of homozygotes than would be expected from an insect-pollinated breeding system and random mating. This may be the result of self-fertilization, which was demonstrated to be possible by Lesica (1993) or due to local nonrandom mating (Baldwin and Brunsfeld 1995). Additional genetic data provided by the Baldwin and Brunsfeld study show a smaller amount of genetic diversity than would be expected "when populations are small and migration of gametes between populations is low due to geographic isolation" as occurs in S. spaldingii. This is explained by and supports a hypothesis "that the geographic distribution was much more extensive than is currently observed, and that the genetic drift is observed to be negligible because of a long generation time" (Baldwin and Brunsfeld 1995).

Additional genetic analyses across more populations are needed to help understand the genetic diversity within and among populations and across the major geographic areas now occupied by S. spaldingii. Because the Dancing Prairie site was the only population included in the Baldwin and Brunsfeld study, little can reliably be said as to the genetic importance of individual populations or the distinct geographic clusters of occurrences in Montana and their importance to the long-term conservation of genetic diversity in the species. 


\section{E. Geographic Distribution and Occurrence Data}

1. Range: Silene spaldingii is distributed within two distinct geographic areas across its range: a tristate area in northeastern Oregon, eastern Washington, and adjoining north-central Idaho, and a smaller area in northwestern Montana with a slight extension into British Columbia, Canada. Five physiographic regions are covered by this distribution: 1) Palouse Grasslands of southeastern Washington and adjacent Idaho, 2) Canyon Grasslands along major river systems in the tristate area of Washington, Idaho and Oregon, 3) Channeled Scablands of east-central Washington, 4) Wallowa Plateau in northeastern Oregon, and 5) Intermontane Valleys of northwestern Montana and British Columbia (Hill and Gray 2004).

Outside of Montana, Silene spaldingii is known from 12 populations in Idaho, 8 in Oregon, 38 in Washington and 1 in British Columbia (Hill and Gray 2004) for a total of 59. Montana is currently believed to have 11 extant populations, bringing the total range-wide to 70 . Numbers reported elsewhere may be slightly higher or lower depending on how occurrences are grouped as populations. Nonetheless, Montana contains approximately $15 \%$ of the total populations and two of the largest known occurrences.

Additionally, 9 of 11 occurrences in Montana occur on lands managed by either the state, the Flathead Indian Reservation or The Nature Conservancy. This compares to $52 \%$ of populations range-wide, which are privately owned (Hill and Gray 2004).

All recently extant occurrences for Montana, including two believed to be recently extirpated, are shown in Figure 4. This excludes two historical occurrences known only from herbarium specimens, one collected near Columbia Falls and the other collected between Hot Springs and Niarada. More detailed maps for each occurrence are presented in the information specific to each one. 


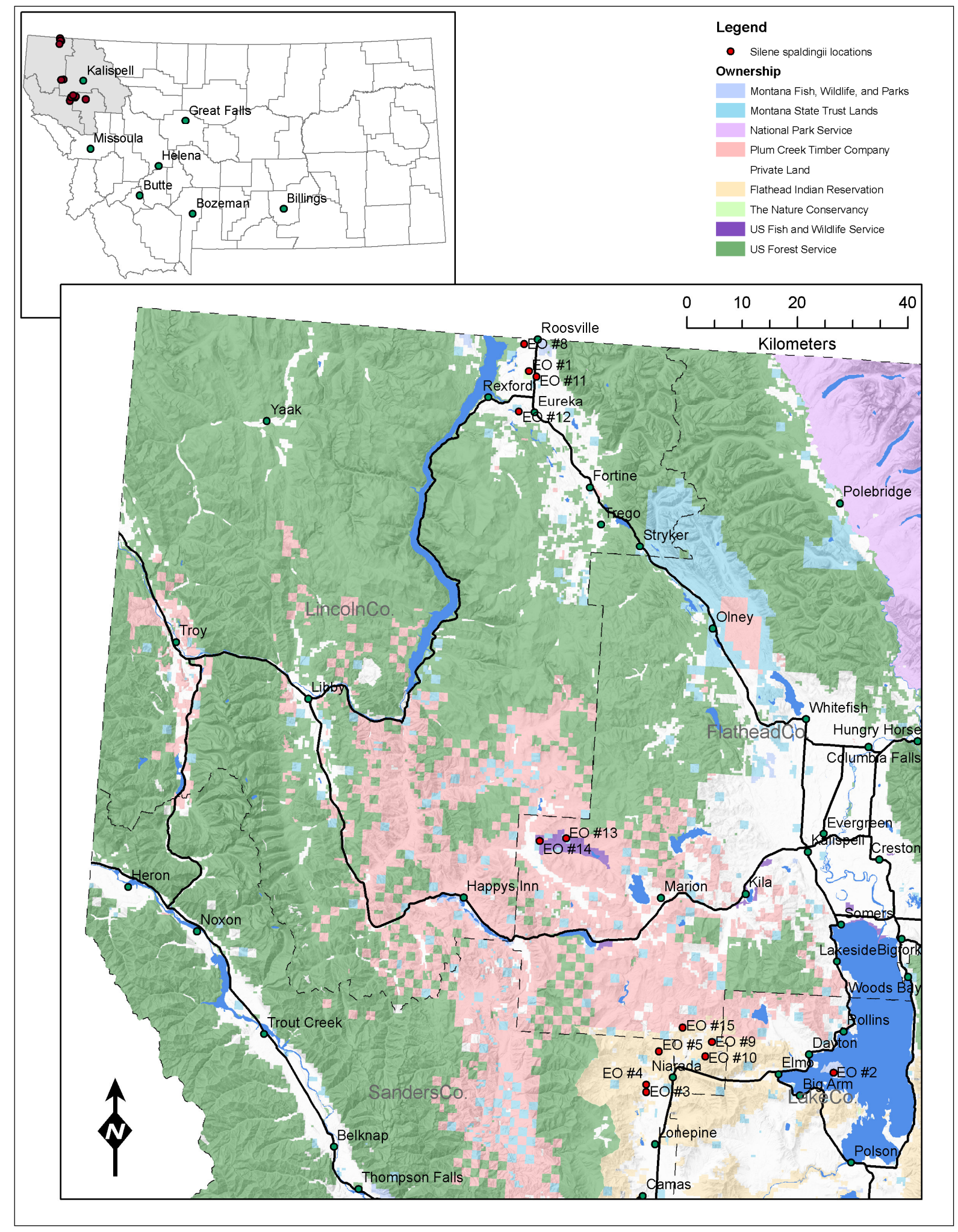

Figure 4. Silene spaldingii locations in Montana. 
2. Historical, Extirpated and Presumed Extirpated Occurrences:

\section{Black Bear Ranch - EO \#3 and Mill Pocket Ridge - EO \#4}

EO Rank: X? - Possibly extirpated

Rank Date: August 9, 2005

Counties: Sanders

Ownership: Private

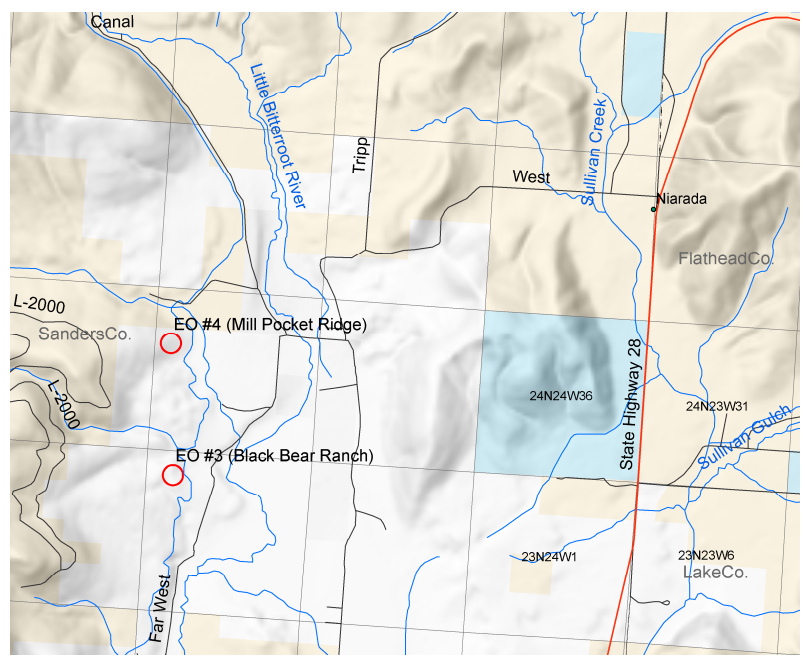

Figure 5. Map of EO \#3 and EO \#4.

Both occurrences were first documented in 1983 with the survey for EO \#3 finding 30 flowering plants and the survey for EO \#4 locating 7 flowering plants. A follow-up survey in 1990 for EO \#3 documented 11 flowering plants. Surveys in 1983 noted the prevalence of exotic species for EO \#3 and by 1990 survey notes stated, "...heavy knapweed invasion where plants were formerly."

In June 2002, the property containing both EO's was sold to the Montana Large Animal Sanctuary and Rescue, which uses the property to graze large numbers of llamas along with smaller numbers of other animals. A 2003 survey noted the area is "severely overgrazed and infested with noxious weeds" and the survey was unsuccessful in finding any S. spaldingii. An additional survey in 2004 near EO \#4 did not locate any plants, and observed the area to be heavily grazed with the few plants present generally being weeds. A conversation with the organization's director in 2005 affirmed the use of the area solely for grazing "large domestic animals" and the unwillingness for future plant surveys to occur on the property. Due to these circumstances the ranks for these two EO's were changed to "possibly extirpated." Even though $S$. spaldingii is known to be a long-lived perennial that may remain dormant for several years, these previously small occurrences appear to have little to no potential long-term viability or conservation value.

\section{Columbia Falls - EO \#6}

EO Rank: H - Historical

This historical occurrence is based on a single specimen collection by R.S. Williams on September 1, 1894, housed at the University of Montana herbarium (MONTU). The sole locality information on the label is "Columbia Falls, Montana." Large areas of potential grassland habitat in the valleys surrounding Columbia Falls have been developed or otherwise altered.

\section{Hot Springs-Niarada - EO \#7}

EO Rank: H - Historical

This occurrence is based on a single specimen collection by D. Lau on June 26, 1974, housed at the University of Montana herbarium (MONTU).

Location information: "Flathead Indian Reservation, Sanders Co., MT. $11 \mathrm{mi} \mathrm{N}$ of Hot Springs junc. on HWY 28. Approx 40 air mi SSW of Kalispell, MT. Basic silty clay soil. Mixed Artemisia grassland, w/ Stipa comata the dom. grass. $\approx 3100$ '."

The area between Niarada and Hot Springs has been searched unsuccessfully for Silene and most of the area supports vegetation that is more xeric than typically present at $S$. spaldingii sites in Montana. It is possible that the location information is inaccurate. The label information would place the collection near EO \#3. 
3. Extant and Presumed Extant Occurrences: Detailed information for each Element Occurrence is provided below. Numbers of Silene spaldingii plants reported in the following tables and writeups are usually mature (flowering and/or fruiting) individuals even if not specifically labeled as such, though in some cases may include immature plants.

\section{Dancing Prairie - EO \#1}

\section{EO Rank: A}

Rank Date: September 1, 2005

Size: 164 hectares (405 ac.)

Counties: Lincoln

Ownership: The Nature Conservancy, Private Elevation: $820 \mathrm{~m}$ to $840 \mathrm{~m}$

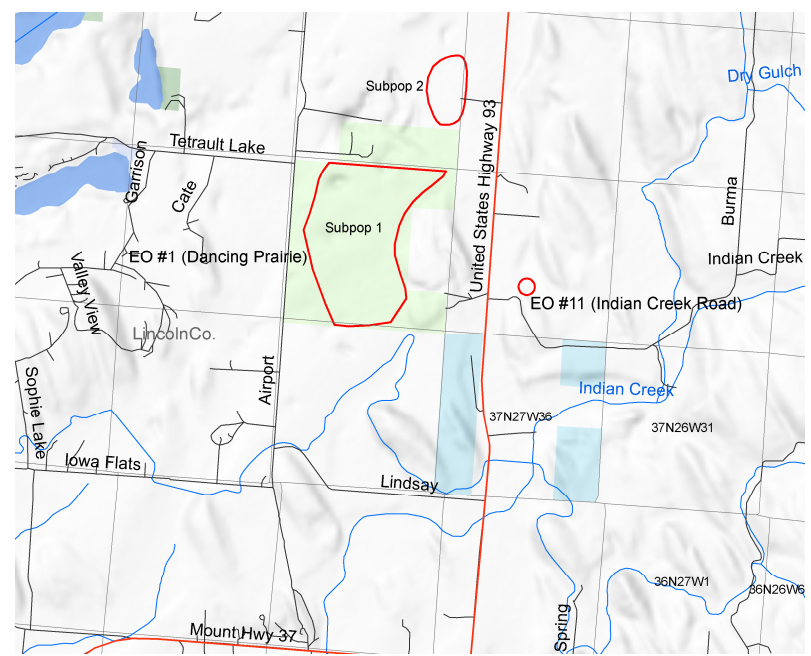

Figure 6. Map of EO \#1 with nearby EO \#11.

\section{Vegetation}

Associated Dominant Species: Festuca scabrella (rough fescue), Festuca idahoensis (Idaho fescue), Stipa comata (needle and thread), Stipa richardsonii (Richardson's needlegrass), Geum triflorum (prairie smoke) and Koeleria macrantha (prairie junegrass).

Exotic Species: Hypericum perforatum (St. Johnswort), Bromus tectorum (cheatgrass), Verbascum thapsus (wooley mullein), Melilotus alba (white sweet clover), Poa pratensis (Kentucky bluegrass), Centaurea maculosa (spotted knapweed), Poa compressa (Canada bluegrass), Verbascum blattaria (moth mullein), Potentilla recta (sulphur cinquefoil), Hieracium pratense (meadow hawkweed) and Bromus inermis (smooth brome).

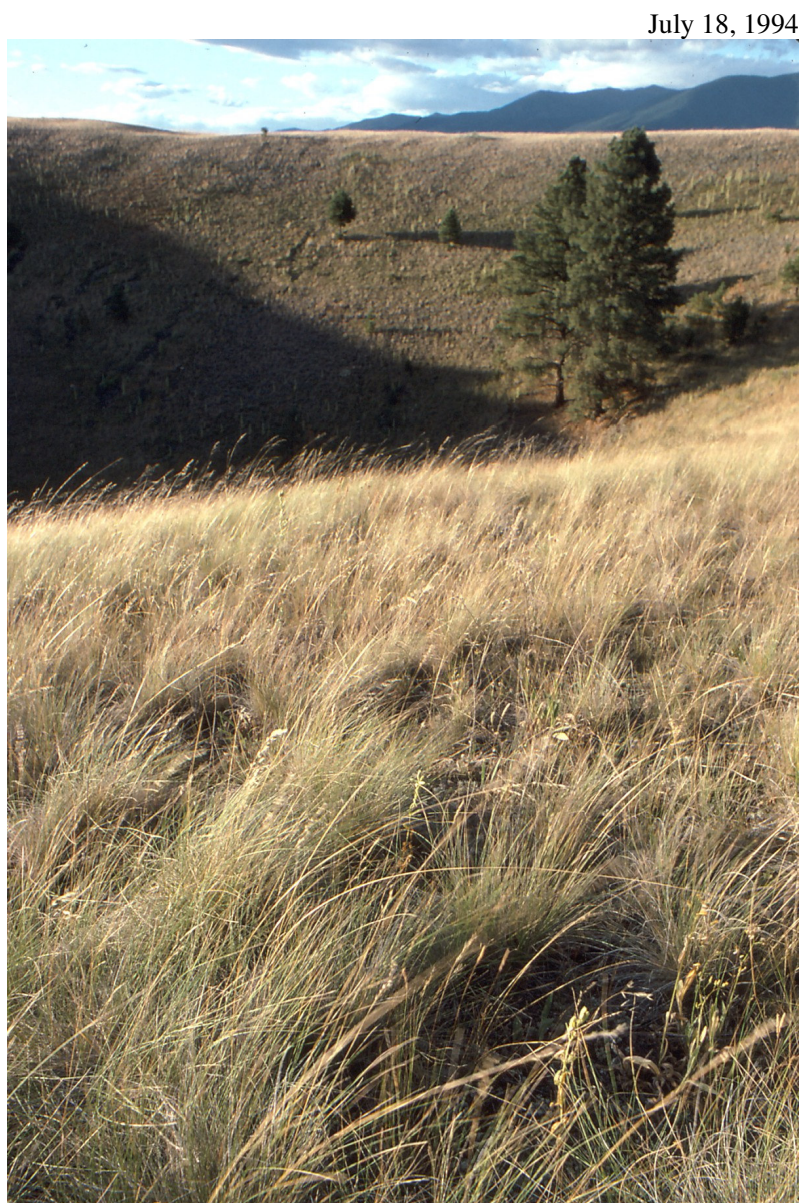

Figure 7. Dancing Prairie Preserve - EO \#1.

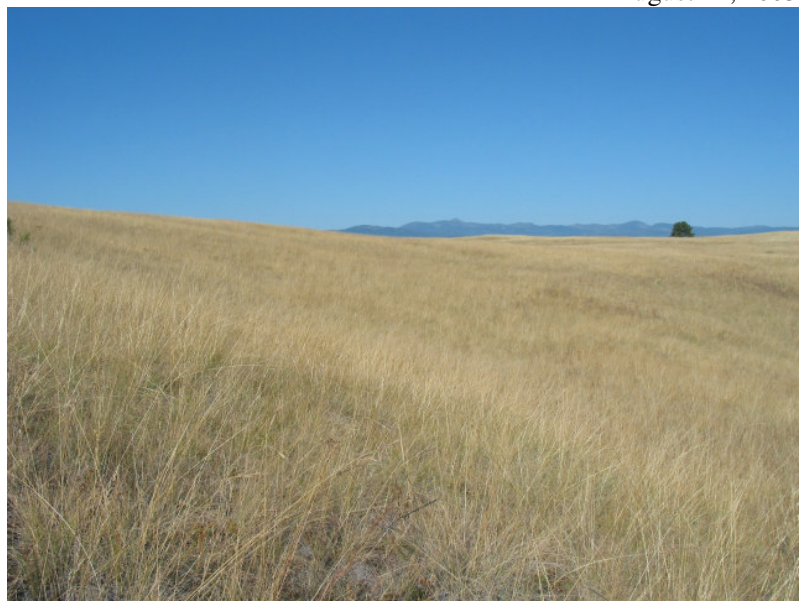

Figure 8. Dancing Prairie Preserve - EO \#1. 
Survey Data

First Observation:

Subpopulation 1: July 16, 1985

Subpopulation 2: June 4, 1986

Last Observation:

Subpopulation 1: August 21, 2005

Subpopulation 2: June 4, 1986

In July 1991, thirty $113 \mathrm{~m}^{2}$ (6 m radius) circular plots were established in the north end of the Preserve. Ten of these plots were randomly assigned as control plots to be used for trend monitoring. A summary of the eight years of available data is provided below (Figure 9) (Lesica 2004).

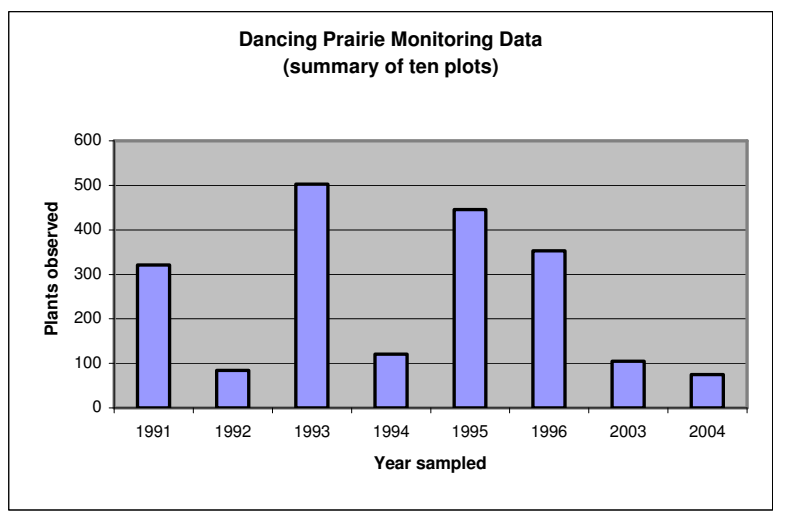

Figure 9. Dancing Prairie monitoring data.

This large population occurs predominantly on the approximately 600 acre Dancing Prairie Preserve owned by The Nature Conservancy. It is located approximately six kilometers north of Eureka in the Tobacco Plains. Fescue-wheatgrass-needlegrass grasslands on rolling glacial terrain dominate the Preserve. Dominant grasses include Festuca scabrella, F. idahoensis and Poa pratensis (Lesica 2004). An additional subpopulation was noted to the north of the Preserve in 1996 on private land.
Little is known about this subpopulation or if it is still extant. S. spaldingii occurs in swales and on northerly aspects with relatively deep soils across the area. Comprehensive survey data across the entire population in any given year generally do not exist. The population was estimated at 10,000 plants in the late 1980's - early 1990's by Peter Lesica, which makes this the largest single population of $S$. spaldingii across its range. This estimate was derived by extrapolating densities of plants observed along monitoring transects across the observed occupied area in the Preserve. It is believed that the estimate is probably conservative and the population may be much larger (Lesica 2003; Lesica, personal communication, 2005).

Invasive species appear to be the main threat to this population. Several invasive weeds are a continuing problem at the Preserve. Control measures have been in place since approximately 1995 and include spot-spraying for weeds from ATV's and backpack sprayers. The main species targeted by this effort include Potentilla recta, Centaurea maculosa, Hieracium pratense and Hypericum perforatum (Lesica 2003).

Additionally, fragmentation of the landscape due to development in the Tobacco Plains will further isolate Dancing Prairie, potentially complicating management and decreasing pollinators.

The Nature Conservancy initiated a prescribed burn plan for the Preserve in the spring of 2003. In the first year, 100 acres of Silene spaldingii habitat were burned and an equivalent amount is expected to be burned every other year (Lesica 2003). Additionally, cattle grazing was suspended when the Preserve was established in 1987 (Lesica 1997). 


\section{Wild Horse Island - EO \#2}

EO Rank: B

Rank Date: September 1, 2005

Size: 7 hectares (18 ac.)

Counties: Lake

Ownership: MT Fish, Wildlife and Parks

Elevation: $975 \mathrm{~m}$ to $990 \mathrm{~m}$

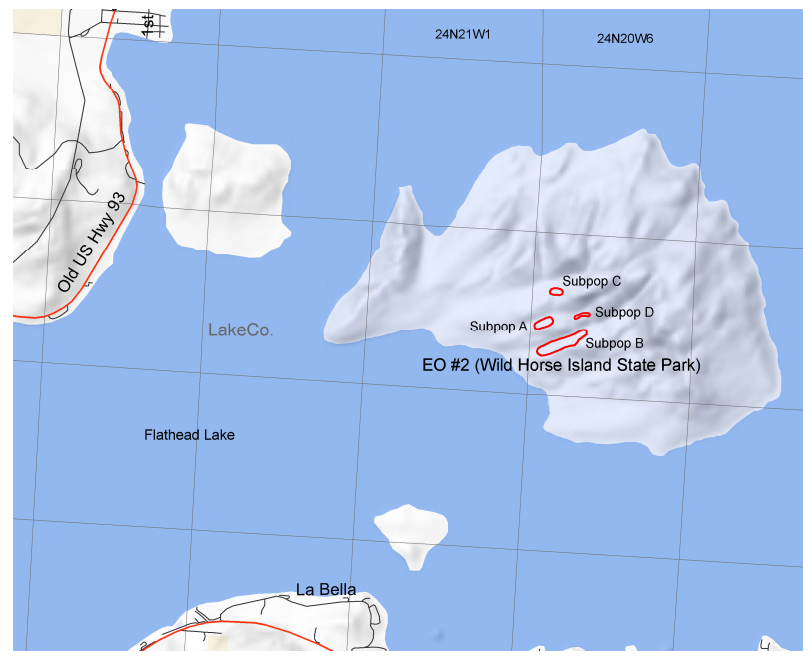

Figure 10. Map of EO \#2.

\section{Vegetation}

Associated Dominant Species: Festuca scabrella, Festuca idahoensis, Elymus spicatus (bluebunch wheatgrass), Lithospermum ruderale (gromwell), Balsamorhiza sagittata (arrowleaf balsamroot) and Pinus ponderosa (ponderosa pine).

\section{Exotic Species: Centaurea maculosa, Bromus} tectorum, and Euphorbia esula (leafy spurge).

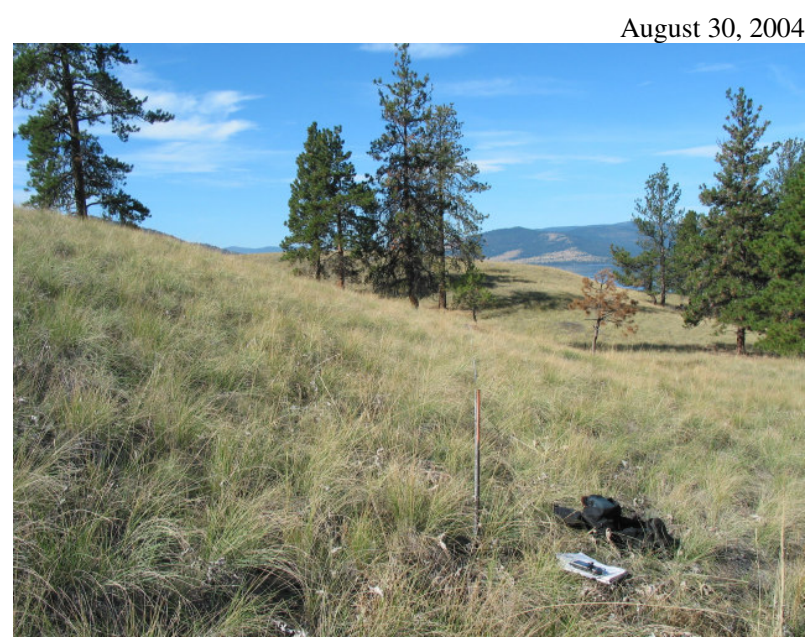

Figure 11. Wild Horse Island - EO \#2, subpop. A.

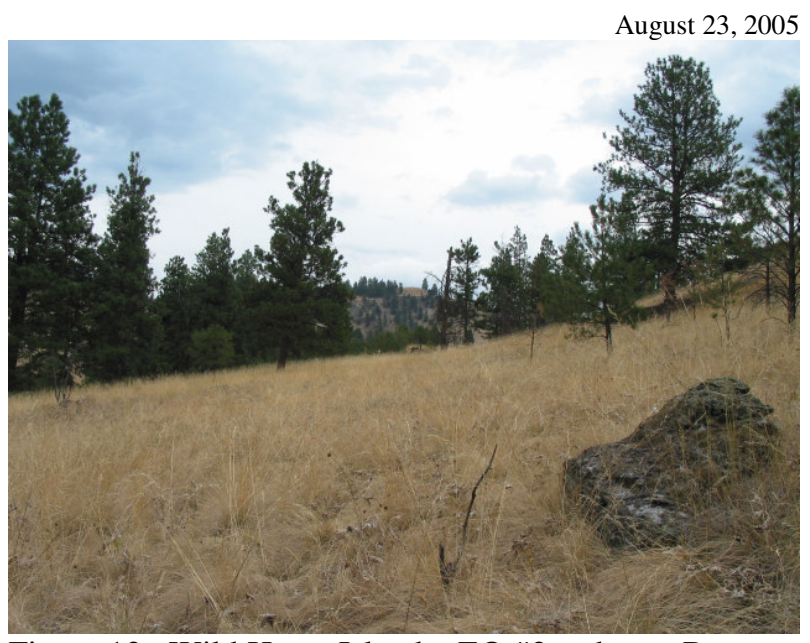

Figure 12. Wild Horse Island - EO \#2, subpop. B.

\section{Survey Data}

\section{First Observation:}

Subpopulation A: July 17, 1983

Subpopulation B: July 17, 1983

Subpopulation C: July 17, 1983

Subpopulation D: August 30, 2004

\section{Last Observation:}

Subpopulation A: August 23, 2005

Subpopulation B: August 23, 2005

Subpopulation C: July 17, 1983

Subpopulation D: August 23, 2005

Table 1. Survey data for EO \#2.

\begin{tabular}{|c|c|c|c|c|c|}
\hline Year & Total & SP A & SP B & SP C & SP D \\
\hline 1983 & $\begin{array}{c}125-250 \\
\text { mature } \\
\text { plants }\end{array}$ & \multicolumn{2}{|c|}{\begin{tabular}{c}
\multicolumn{2}{|c|}{ Breakdown among } \\
subpopulations unavailable.
\end{tabular}} & -- \\
\hline 2003 & $\begin{array}{c}4 \text { mature } \\
\text { plants }\end{array}$ & 0 & 4 & 0 & -- \\
\hline 2004 & $\begin{array}{c}12 \\
\text { mature } \\
\text { plants }\end{array}$ & 9 & NA & 0 & 3 \\
\hline $\begin{array}{c}22 \\
\text { mature } \\
\text { plants }\end{array}$ & 9 & 12 & 0 & 1 \\
\hline
\end{tabular}

NA = subpopulation not sampled or total population count/estimate not available for this year.

-- = subpopulation not known at the time of this survey.

In 1986, two $50 \mathrm{~m}$ permanent belt transects were established by Peter Lesica in subpopulation A. Fifty adjacent $1 \mathrm{~m}^{2}$ plots are measured along each transect (Lesica 1986). The eight years of available data are summarized in Figure 13. 


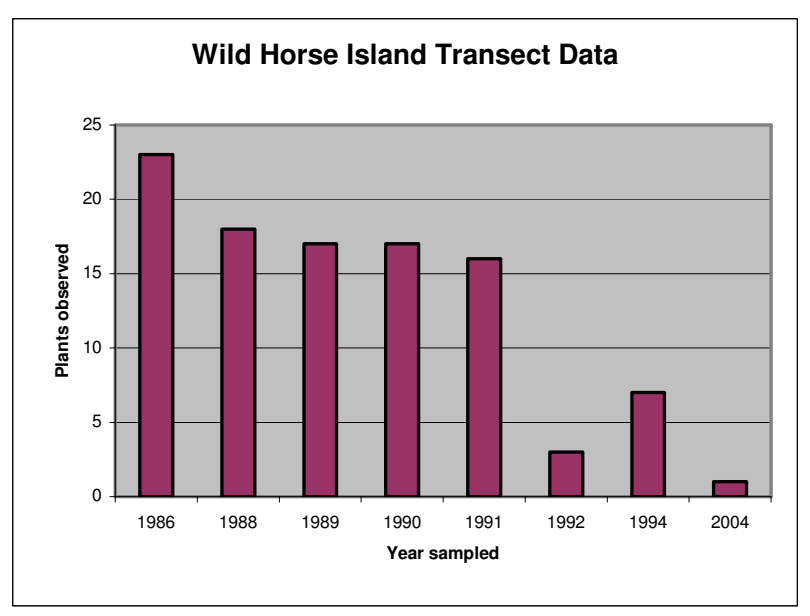

Figure 13. Wild Horse Island monitoring data. The 2004 sampling may have missed immature plants due to the late sampling date.

This population occurs on the southwest side of Wild Horse Island, a 2,100-acre island in Flathead Lake. The population of $S$. spaldingii occurs entirely within the boundaries of Wild Horse Island State Park, which encompasses the majority of the island. The occurrence was first documented in 1983 and was estimated to contain between 125250 S. spaldingii plants. Follow-up surveys in 2003-2005 have documented far fewer plants in the four mapped subpopulations and have failed to locate any plants in Subpopulation C. The population generally occurs along northerly aspects of southwest trending draws. The vegetation associated with the population is dominated by dense Festuca scabrella along with F. idahoensis, Elymus spicatus, Lithospermum ruderale and Balsamorhiza sagittata. Scattered Pinus ponderosa are also present in two of the subpopulations. Few weeds are present in the area, with Bromus tectorum being the most frequent invasive species and minor amounts of Centaurea maculosa and Euphorbia esula also documented near the population.

The main threat to this population appears to be from increased competition, particularly from Festuca scabrella. The F. scabrella in the area are large, dense and have heavy thatch buildup and appear to negatively impact survival, growth and reproduction of $S$. spaldingii on the island. It is believed that the area has missed at least several fire return intervals and a re-introduction of fire to the population may be necessary to ensure its viability. However, burning the site may have the detrimental side effect of opening it up to weed invasion, particularly from Bromus tectorum. Currently, weeds are not a direct threat to the population and an occurrence of Euphorbia esula nearby is being controlled by the state (private landowner, personal communication, 2005). 


\section{Crosson Valley - EO \#5}

EO Rank: A

Rank Date: September 17, 2004

Size: 52 hectares (129 ac.)

Counties: Flathead, Sanders

Ownership: Flathead Indian Reservation

Elevation: $1020 \mathrm{~m}$ to $1085 \mathrm{~m}$

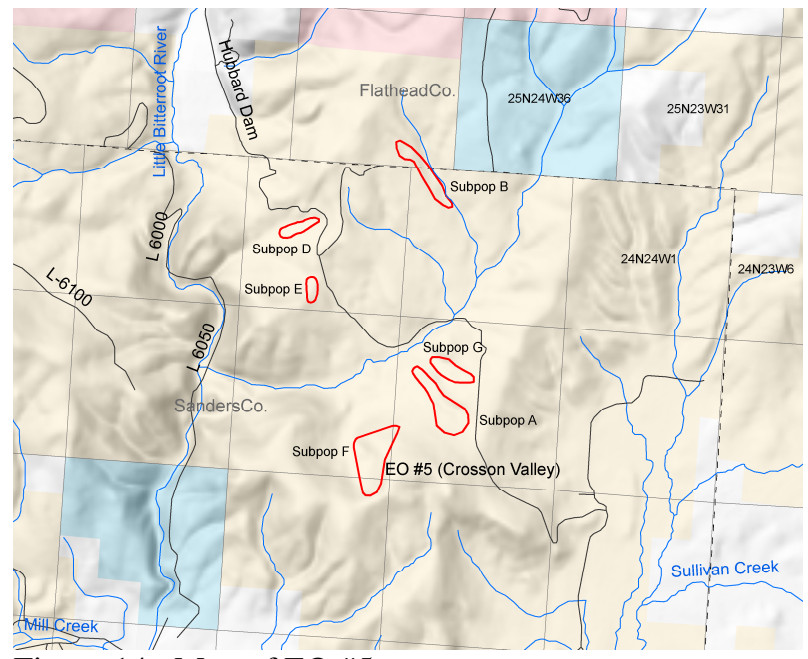

Figure 14. Map of EO \#5.

\section{$\underline{\text { Vegetation }}$}

Associated Dominant Species: Festuca scabrella, Stipa nelsonii (Nelson's needlegrass), Koeleria macrantha, Achillea millefolium (yarrow), Monarda fistulosa (beebalm), Stipa richardsonii, Lithospermum ruderale, Danthonia intermedia (timber oatgrass), Lupinus sericeus (silky lupine) and Poa secunda (Sandberg's bluegrass).

Exotic Species: Potentilla recta, Centaurea maculosa, Bromus tectorum and Poa pratensis.
August 17, 2003

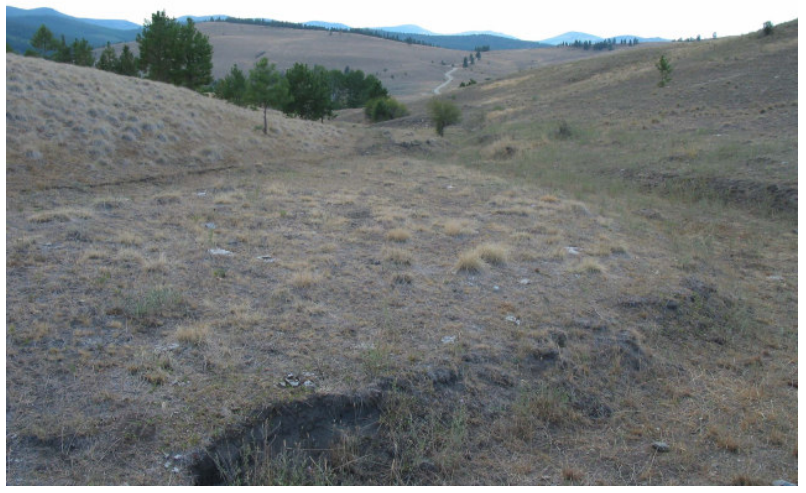

Figure 15. Crosson Valley - EO \#5, subpop. A.

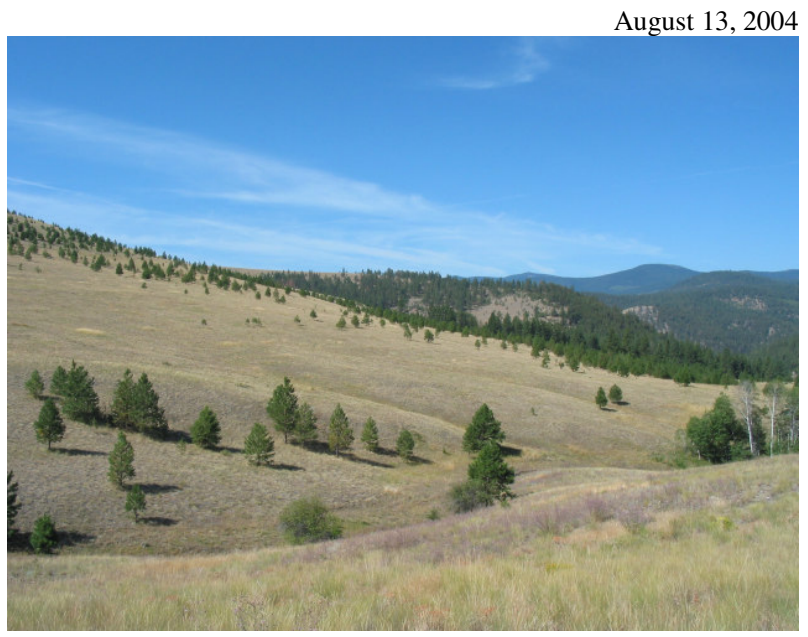

Figure 16. Crosson Valley - EO \#5, subpop. A.

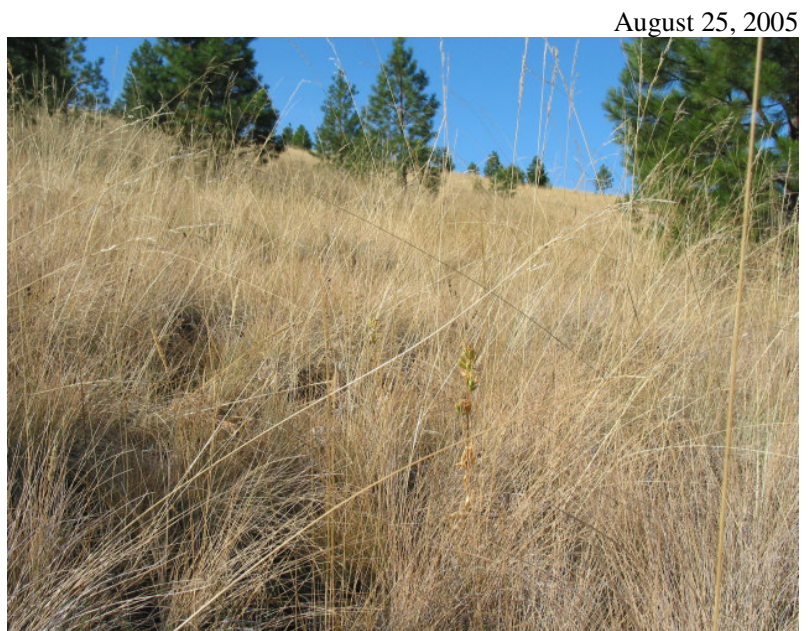

Figure 17. Crosson Valley - EO \#5, subpop. F. 
Survey Data

First Observation:

Subpopulation A: July 29, 1983

Subpopulation B: July 29, 1983

Subpopulation D: July 29, 1983

Subpopulation E: July 29, 1983

Subpopulation F: August 1, 1989

Subpopulation G: August 13, 2004

Last Observation:

Subpopulation A: August 13, 2004

Subpopulation B: August 13, 2004

Subpopulation D: August 13, 2004

Subpopulation E: August 6, 2003

Subpopulation F: August 25, 2005

Subpopulation G: August 13, 2004

Table 2. Survey data for EO \#5.

\begin{tabular}{|c|c|c|c|c|c|c|c|}
\hline Year & Total & $\begin{array}{c}\text { SP } \\
\text { A }\end{array}$ & $\begin{array}{c}\text { SP } \\
\text { B }\end{array}$ & $\begin{array}{c}\text { SP } \\
\text { D }\end{array}$ & $\begin{array}{c}\text { SP } \\
\text { E }\end{array}$ & $\begin{array}{c}\text { SP } \\
\text { F }\end{array}$ & $\begin{array}{c}\text { SP } \\
\text { G }\end{array}$ \\
\hline 1983 & $\begin{array}{c}129 \\
\text { mature } \\
\text { plants }\end{array}$ & 40 & 29 & 50 & 10 & -- & -- \\
\hline 1988 & $\begin{array}{c}\text { Much } \\
\text { reduced } \\
\text { in size }\end{array}$ & NA & NA & NA & NA & -- & -- \\
\hline 1989 & NA & NA & NA & NA & NA & 27 & -- \\
\hline 2003 & 13 & 6 & 0 & 5 & 2 & NA & -- \\
\hline 2004 & $\begin{array}{c}635 \\
\text { mature } \\
\text { plants }\end{array}$ & 424 & 53 & 7 & 0 & NA & 151 \\
\hline 2005 & NA & NA & NA & NA & NA & 26 & NA \\
\hline
\end{tabular}

* Subpopulation C combined with subpopulation B in 2005.

This large population north of Niarada on the Flathead Indian Reservation spans six known subpopulations occupying approximately 52 hectares. Five of the subpopulations were surveyed in 2004 and the remaining subpopulation was surveyed in 2005. Results of these surveys counted 651 mature plants, meaning the total population when considering seedlings/rosettes and dormant plants is probably close to 1000 plants. This places the Crosson Valley population as the second largest in Montana and one of the largest range-wide. Estimates of population size prior to 2004 were substantially lower and this population has not been considered a conservation priority in previous assessments (Hill and Gray 2004). Two subpopulations contain most of the documented plants, with subpopulation $\mathrm{G}$ being documented for the first time in 2004. Surrounding areas appear to have more suitable habitat that remains unsurveyed or at least not surveyed in a "good" year,

suggesting the possibility that further expansion of the known extent of this population is good.

Vegetation is generally in good shape across this EO. Dominant species vary across the subpopulations but generally include Festuca scabrella, Stipa nelsonii, Koeleria macrantha, Achillea millefolium, Monarda fistulosa and Stipa richardsonii along with scattered Pinus ponderosa. Invasive weeds are present in the population with the most notable ones observed being Potentilla recta, Centaurea maculosa and Bromus tectorum. Generally they are only scattered in distribution, except for subpopulation B where weeds are common.

Cattle grazing occurs in all the subpopulations, though generally does not appear to be having substantial negative effects. Subpopulation B appears to be receiving the highest amount of grazing use and also appears to have more weeds than the other areas. Areas surrounding this subpopulation, particularly to the east, are severely impacted by noxious weeds and were observed to be heavily grazed in 2004 and 2005. Besides loss of habitat due to weed invasion, no other substantial threats to this population are currently evident. 
Roosville - EO \#8 (formerly known as Tobacco Plains North)

EO Rank: CD

Rank Date: September 1, 2005

Size: 8 hectares (20 ac.)

Counties: Lincoln

Ownership: Private

Elevation: $815 \mathrm{~m}$ to $820 \mathrm{~m}$

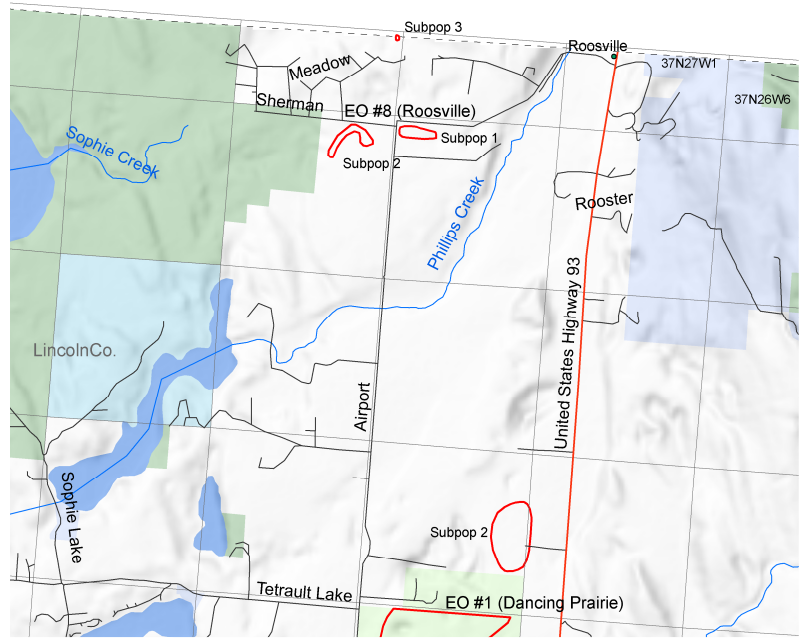

Figure 18. Map of EO \#8 with nearby EO \#1.

Vegetation

Associated Dominant Species: Festuca scabrella, Festuca idahoensis, Stipa comata, Geum triflorum and Monarda fistulosa.

Exotic Species: Potentilla recta, Centaurea maculosa and Poa compressa.

July 21, 1988

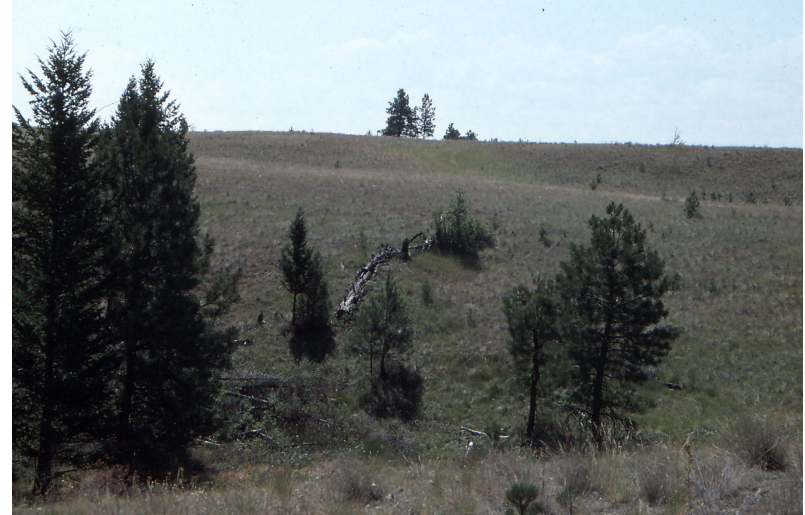

Figure 19. Roosville - EO \#8, subpopulation 3? (location of photograph uncertain)
Survey Data

First Observation:

Subpopulation 1: July 17, 1986

Subpopulation 2: August 6, 1993

Subpopulation 3: July 18, 1988

Last Observation:

Subpopulation 1: July 17, 1986

Subpopulation 2: August 6, 1993

Subpopulation 3: August 5, 2003

Table 3. Survey data for EO \#8.

\begin{tabular}{|c|c|c|c|c|}
\hline Year & Total & SP 1 & SP 2 & SP 3 \\
\hline 1986 & NA & $\begin{array}{c}\text { Locally } \\
\text { common }\end{array}$ & -- & -- \\
\hline 1988 & NA & NA & -- & 6 \\
\hline 1989 & NA & NA & -- & 27 \\
\hline 1993 & NA & NA & $32+$ & NA \\
\hline 2003 & NA & 0 & NA & 7 \\
\hline
\end{tabular}

This population is 13 kilometers north of Eureka and occurs entirely on private lands. The occurrence is composed of three subpopulations with one occurring at the Canadian border and evidently extending across the border into Canada. The population was first observed in 1986 and follow-up surveys have occurred in 1988, 1989, 1993 and 2003. The population occurs in valley grasslands formed in rolling, kettle/drumlin topography. Dominant species include Festuca scabrella, Festuca idahoensis, Stipa comata, Geum triflorum and Monarda fistulosa. Weeds that have been noted during surveys include Potentilla recta, Centaurea maculosa and Poa compressa.

Development and housing subdivisions now dot the area occupied by this population.

Subpopulations 1 and 3 have houses built adjacent to them according to the 2003 survey, and subpopulation 1 was searched unsuccessfully in 2003. During 2005 the area was observed from local roads and not directly surveyed. These observations verify that development and subdivision are occurring. In a best-case scenario, $S$. spaldingii plants in this population will be relegated to highly fragmented habitat and potentially will be lost entirely to development in the years to come. 


\section{Cromwell Creek - EO \#9}

EO Rank: C

Rank Date: September 1, 2005

Size: 1.5 hectares $(4 \mathrm{ac}$.)

Counties: Flathead

Ownership: Flathead Indian Reservation

Elevation: $1040 \mathrm{~m}$ to $1070 \mathrm{~m}$

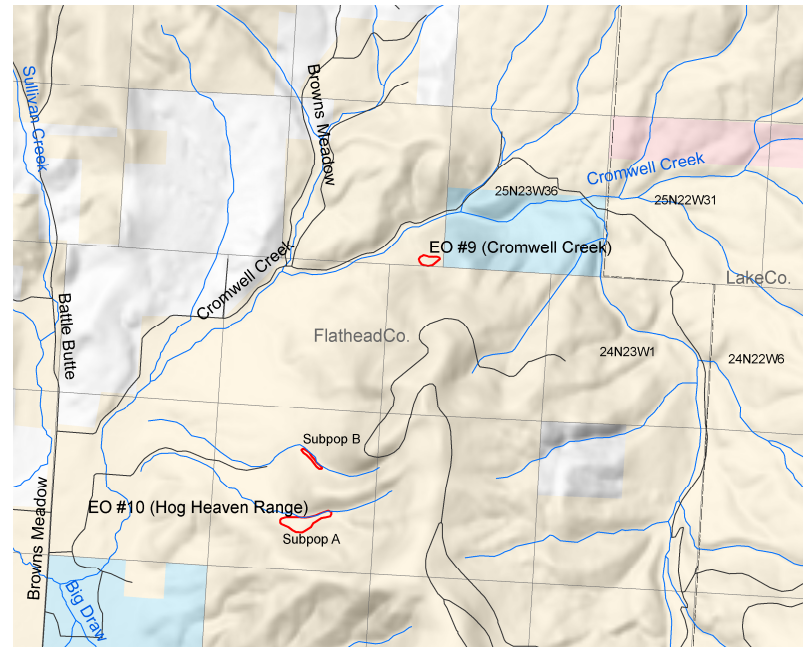

Figure 20. Map of EO \#9 with nearby EO \#10.

$\underline{\text { Vegetation }}$

Associated Dominant Species: Festuca scabrella, Geum triflorum, Geranium viscosissimum (sticky geranium) and Potentilla glandulosa (sticky cinquefoil).

Exotic Species: Hypericum perforatum, Centaurea maculosa, Bromus tectorum, Potentilla recta and Dianthus armeria (Deptford pink).

July 22, 1988

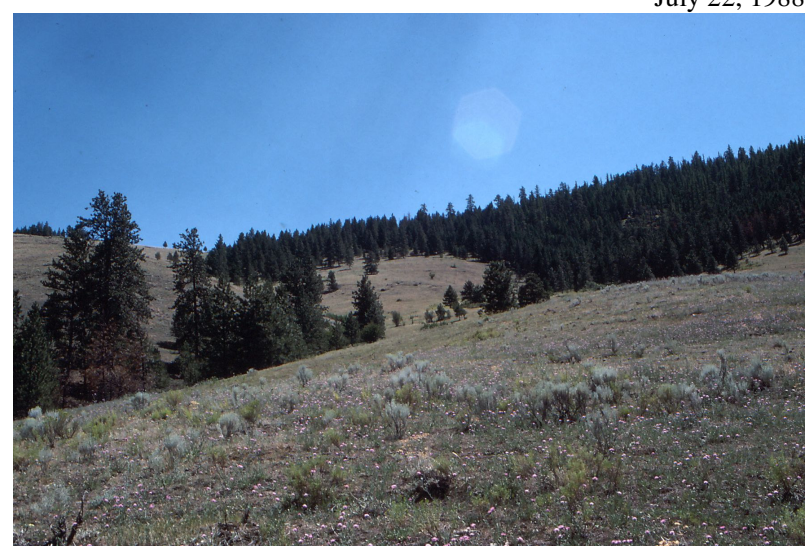

Figure 21. Cromwell Creek - EO \#9.

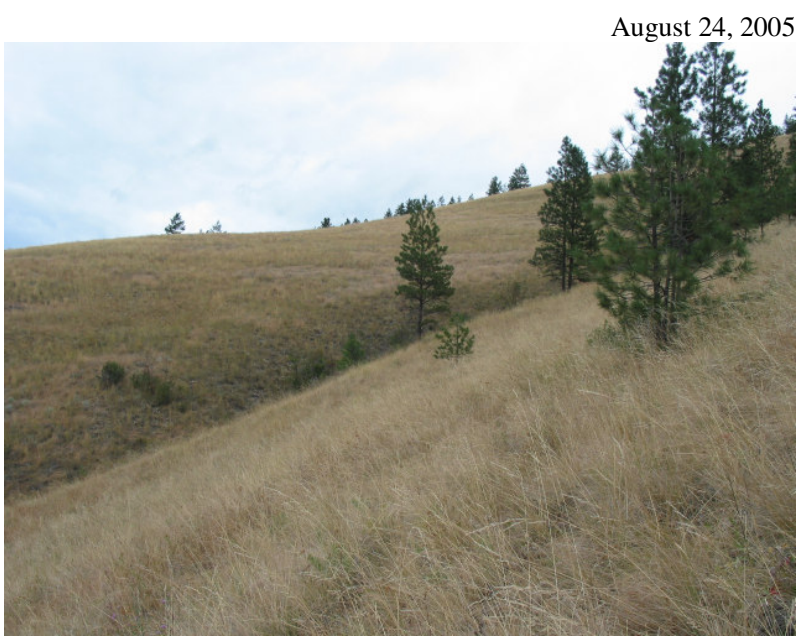

Figure 22. Cromwell Creek - EO \#9.

\section{Survey Data}

First Observation: July 22, 1988

Last Observation: August 24, 2005

Table 4. Survey data for EO \#9.

\begin{tabular}{|c|c|}
\hline Year & Total \\
\hline 1988 & 10 mature plants \\
\hline 2003 & 17 mature plants \\
\hline 2004 & 0 plants \\
\hline 2005 & 27 mature plants \\
\hline
\end{tabular}

This small population on the Flathead Indian Reservation occurs 9.5 kilometers northeast of Niarada. First documented in 1988, follow-up surveys were conducted in 2003, 2004 and 2005. The highest count for this site occurred in 2005 with 27 flowering/fruiting plants observed in an area of approximately one acre. The population occurs on a steep, north-facing slope of the Hog Heaven Range and is approximately two kilometers from EO \#10 and may be considered part of the same population. Dominant species include Festuca scabrella, Geum triflorum, Geranium viscosissimum and Potentilla glandulosa. The condition of the grassland is good with few weeds present on the site, though small amounts of Hypericum perforatum, Centaurea maculosa, Bromus tectorum, Potentilla recta and Dianthus armeria do occur. Immediately below the occurrence, on the same slope, several of these 
invasive weeds are abundant and grazing was noted to be moderate to heavy in 1988 and 2003-2005. Short- and long-term grazing plans for the site are unknown.

This small population, though not currently impacted by weeds, has a high potential to be detrimentally impacted by invasive weeds in the future. Management action to control weeds at and adjacent to the site will likely be needed to ensure the continued viability of the population. 


\section{Hog Heaven Range - EO \#10}

EO Rank: B

Rank Date: September 17, 2004

Size: 5.5 hectares (14 ac.)

Counties: Flathead

Ownership: Flathead Indian Reservation

Elevation: $1085 \mathrm{~m}$ to $1160 \mathrm{~m}$

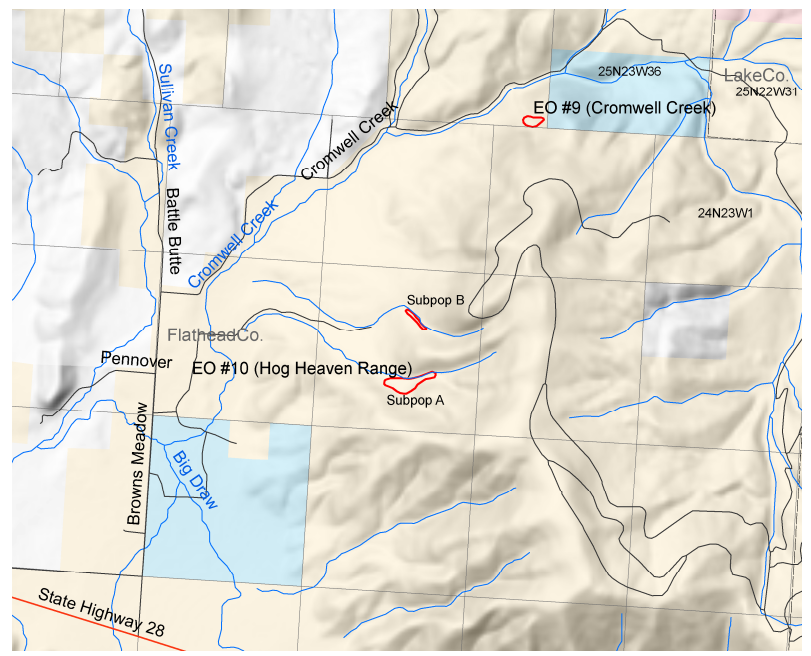

Figure 23. Map of EO \#10 with nearby EO \#9.

$\underline{\text { Vegetation }}$

Associated Dominant Species: Festuca idahoensis, Elymus spicatus, Stipa nelsonii, Lupinus sericeus, Monarda fistulosa and Rosa woodsii (Wood's rose).

Exotic Species: Centaurea maculosa, Potentilla recta, Bromus tectorum, and Sisymbrium altissimum (tall tumblemustard).

August 27, 2004

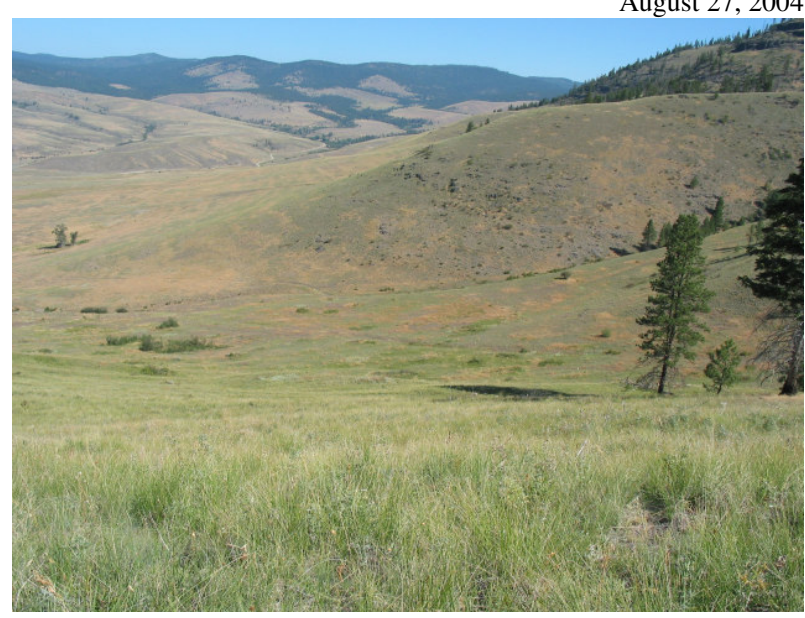

Figure 24. Hog Heaven Range - EO \#10, subpop. A.
Survey Data

First Observation:

Subpopulation A: July 27, 1988

Subpopulation B: August 27, 2004

Last Observation:

Subpopulation A: August 27, 2004

Subpopulation B: August 27, 2004

Table 5. Survey data for EO \#10.

\begin{tabular}{|c|c|c|c|}
\hline Year & Total & SP A & SP B \\
\hline 1988 & 12 mature plants & 12 & -- \\
\hline 2004 & 173 mature plants & 154 & 19 \\
\hline
\end{tabular}

This population on the Flathead Indian Reservation is located seven kilometers northeast of Niarada and was first documented in 1988 with 12 plants. The only follow-up survey was conducted in 2004 when 173 flowering/fruiting plants were observed in two subpopulations, making this the third largest in the state according to recent surveys. The population occurs on the lower slopes of the Hog Heaven Range directly below treeline and covers 5.5 hectares. Both subpopulations are found on northerly to westerly aspects of west-facing draws. Dominant species at the site include Festuca idahoensis, Elymus spicatus, Stipa nelsonii, Lupinus sericeus, Monarda fistulosa and Rosa woodsii. Weeds were abundant at the site in 2004 and included Centaurea maculosa, Potentilla recta, Bromus tectorum, and Sisymbrium altissimum. $C$. maculosa and S. altissimum both occurred in dense patches throughout the area. Grazing, although permitted, was not occurring at the time of the 2004 survey.

The abundance of invasive weeds on this site is likely to be detrimental to the long-term viability of S. spaldingii. Grazing, though not an observed threat in 2004, was noted to be a problem in 1988 and the quality of the site was noted to be poor at that time. Active management of grazing operations and weed control will probably be needed at the site to ensure the viability of the population. Short- and long-term grazing plans for the site are unknown. 


\section{Indian Creek Road - EO \#11}

EO Rank: C

Rank Date: August 21, 1989

Size: $\approx 0.01$ hectare $(0.02 \mathrm{ac}$. $)$

Counties: Lincoln

Ownership: Private

Elevation: $850 \mathrm{~m}$

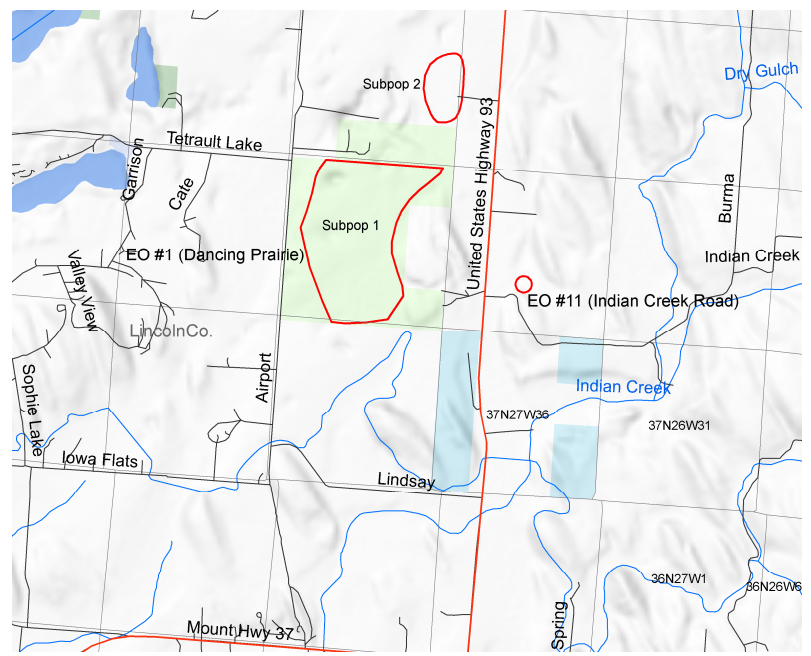

Figure 25. Map of EO \#11 with nearby EO \#1.

Vegetation

Associated Dominant Species: Festuca scabrella, Rosa woodsii, Festuca idahoensis, Geranium viscosissimum, Stipa comata and Balsamorhiza sagittata.

Exotic Species: Unknown.

No photos available for this EO.
Survey Data

First Observation: 1988

Last Observation: August 21, 1989

Table 6. Survey data for EO \#11.

\begin{tabular}{|c|c|}
\hline Year & Total \\
\hline 1988 & 1 mature plant \\
\hline 1989 & 23 mature plants \\
\hline
\end{tabular}

This small population, six kilometers north of Eureka on private land, was first discovered in 1988 with one plant observed. The only successful follow-up visit occurred in 1989. Permission to access the area in 2003 by Montana Natural Heritage Program staff was denied. The population occurs near the boundary of three private properties and the actual ownership on which the population occurs is uncertain at this time. The site is described in the 1989 survey as "an open, northwest-facing midslope in Festuca scabrella grasslands near the trees." Associated species include Festuca scabrella, Rosa woodsii, Festuca idahoensis, Geranium viscosissimum, Stipa comata and Balsamorhiza sagittata. Due to the long interval since a site visit has occurred, little can be said as to the status of the population or its conservation value. Due to its close proximity to the Dancing Prairie population, this occurrence may best be treated as a part of that larger occurrence as it was by Hill and Gray (2004). 


\section{Black Lake - EO \#12}

EO Rank: B

Rank Date: September 1, 2005

Size: 2 hectares $(6 \mathrm{ac}$.)

Counties: Lincoln

Ownership: MT State Trust Lands

Elevation: $845 \mathrm{~m}$ to $860 \mathrm{~m}$

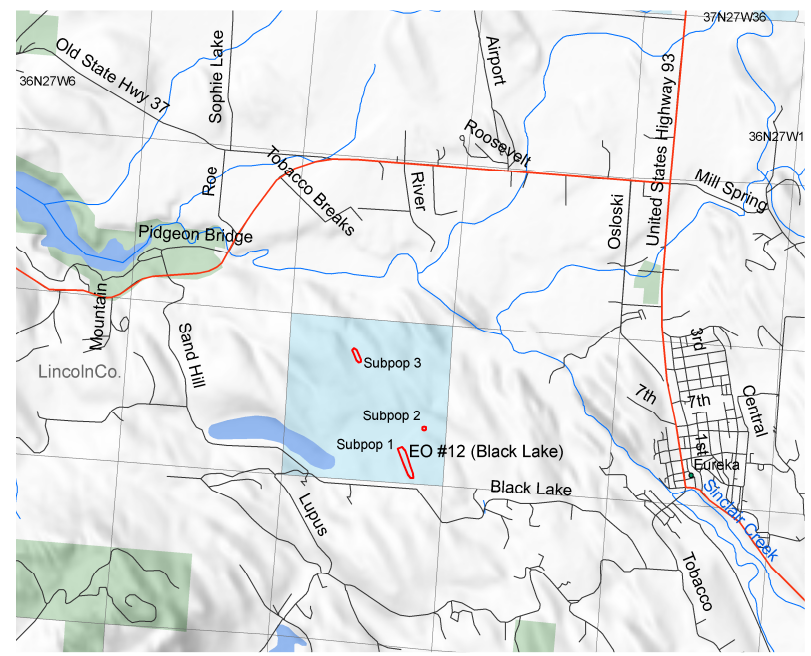

Figure 26. Map of EO \#12.

\section{Vegetation}

Associated Dominant Species: Stipa richardsonii, Festuca scabrella, Lithospermum ruderale and Symphoricarpos albus (common snowberry).

Exotic Species: Potentilla recta, Centaurea maculosa and Poa pratensis.

August 21, 2005

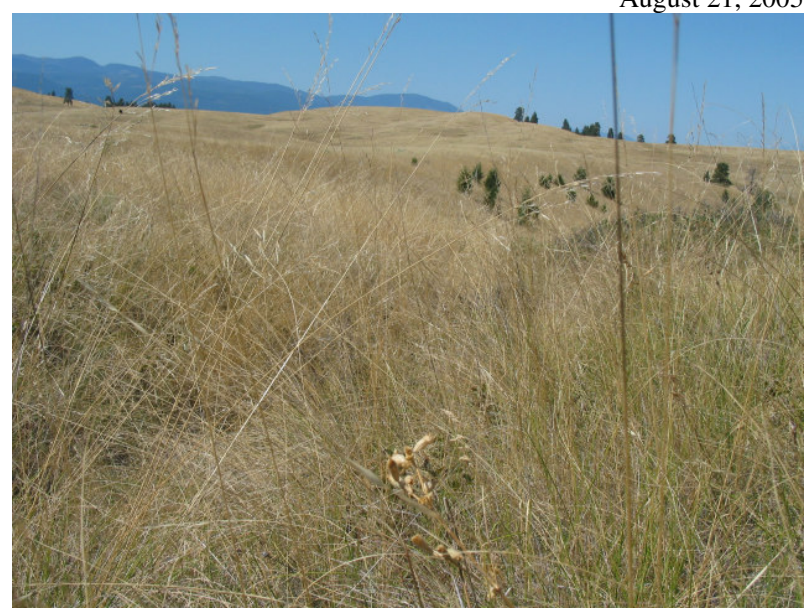

Figure 27. Black Lake - EO \#12, subpopulation 1.
Survey Data

First Observation: August 21, 2005

Last Observation: August 21, 2005

Table 7. Survey data for EO \#12.

\begin{tabular}{|c|c|c|c|c|}
\hline Year & Total & SP 1 & SP 2 & SP 3 \\
\hline 2005 & $\begin{array}{c}18 \\
\text { mature } \\
\text { plants }\end{array}$ & 12 & 2 & 4 \\
\hline
\end{tabular}

This small population was discovered in 2005 on an isolated section of Montana State Trust Land approximately three kilometers west of Eureka. $S$. spaldingii plants occur along north-facing draws and slopes in three subpopulations, occupying an area of two hectares. Cattle were grazing the section during the survey, though not generally in areas where S. spaldingii was growing. Associated dominant species include Stipa richardsonii, Festuca scabrella, Lithospermum ruderale and Symphoricarpos albus. Few invasive weeds were present, though Potentilla recta and Centaurea maculosa both occurred in minor amounts. Poa pratensis was abundant in some areas but not directly at the observed $S$. spaldingii locations.

Overall, the condition of the habitat at this site is good, though the bunchgrasses are dense and wolfy with heavy thatch build-up. This may result in increased competition compared to historical conditions that may be detrimental to the continued survival and reproduction of $S$. spaldingii at this location. Prescribed burning at the site may be necessary to re-invigorate the population and decrease competition and thatch build-up from native bunchgrasses. The high-quality, intact grasslands on this state owned section increase the conservation value of the population and may increase the probability of long-term beneficial management options. Short- and long-term grazing plans for the site are unknown. Additional potential suitable habitat on the state section and adjacent private lands were not searched. 


\section{Lost Trail NWR East - EO \#13}

\section{EO Rank: B}

Rank Date: September 1, 2005

Size: 1.25 hectares ( 3 ac.)

Counties: Flathead

Ownership: MT State Trust Lands

Elevation: $1085 \mathrm{~m}$ to $1160 \mathrm{~m}$

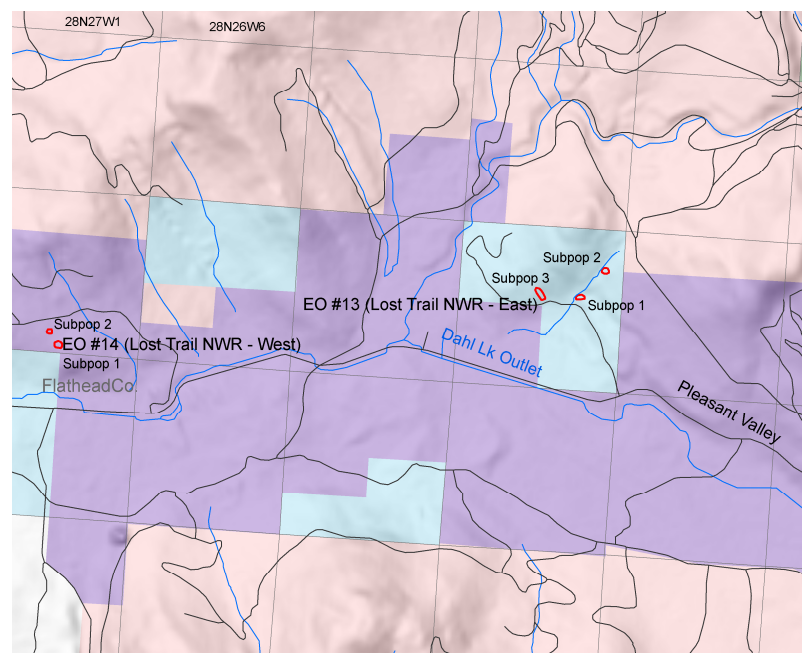

Figure 28. Map of EO \#13 with nearby EO \#14.

\section{Vegetation}

Associated Dominant Species: Festuca scabrella, Festuca idahoensis, Stipa richardsonii, Elymus spicatus, Geum triflorum and Koeleria macrantha.

Exotic Species: Hypericum perforatum, Potentilla recta, Poa compressa and Poa pratensis.

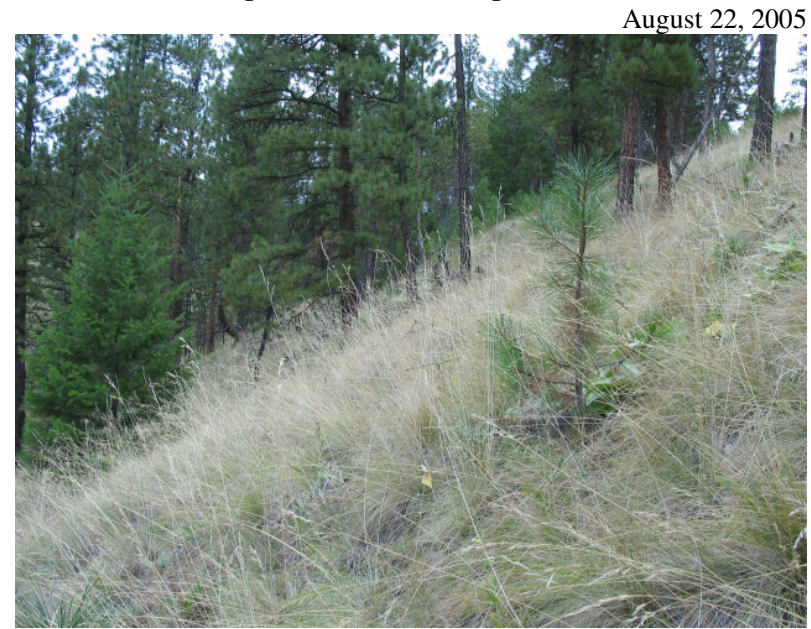

Figure 29. Lost Trail NWR East - EO \#13, subpop. 2.
Survey Data

First Observation: 2002

Last Observation: August 22, 2005

Table 8. Survey data for EO \#13.

\begin{tabular}{|c|c|c|c|c|}
\hline Year & Total & SP 1 & SP 2 & SP 3 \\
\hline 2005 & $\begin{array}{c}21 \\
\text { mature } \\
\text { plants }\end{array}$ & 14 & 3 & 4 \\
\hline
\end{tabular}

This population was apparently discovered in 2002, though original documentation for the occurrence is unavailable. The population occurs on a 480acre tract of state land surrounded by the Lost Trail National Wildlife Refuge on three sides and by Plum Creek Timber Company lands to the north. This occurrence is approximately five kilometers east of EO \#14 (Lost Trail NWR West) and EO $\# 13$ and \#14 have been reported as being one population in previous reports (Hill and Gray 2004). If additional $S$. spaldingii plants are documented between these two occurrences, then that may eventually be the best way to treat them since the unoccupied distance will be much smaller. See EO \#14 for further discussion about population size and survey data pertinent to the Lost Trail NWR occurrences.

Threats to this occurrence appear to be minimal at the current time. Several exotic species are present in the vicinity though none currently pose immediate threats. It is likely that control measures will eventually need to be implemented to contain Hypericum perforatum and Potentilla recta within the occupied $S$. spaldingii habitat.

Two permanent belt transects measuring $15 \mathrm{~m}$ and $24 \mathrm{~m}$ were established in subpopulation 1 in 2004 for a demographic monitoring study (Lesica and Crone 2004). Data are not presented here due to the limited survey data available as of this report, though the study should provide meaningful trend data in future years.

More survey work is needed in the area to determine the actual size and extent of the population. 


\section{Lost Trail NWR West - EO \#14}

EO Rank: B

Rank Date: September 1, 2005

Size: 0.6 hectare $(1.5 \mathrm{ac}$.)

Counties: Flathead

Ownership: Lost Trail National Wildlife Refuge Elevation: $1130 \mathrm{~m}$ to $1145 \mathrm{~m}$

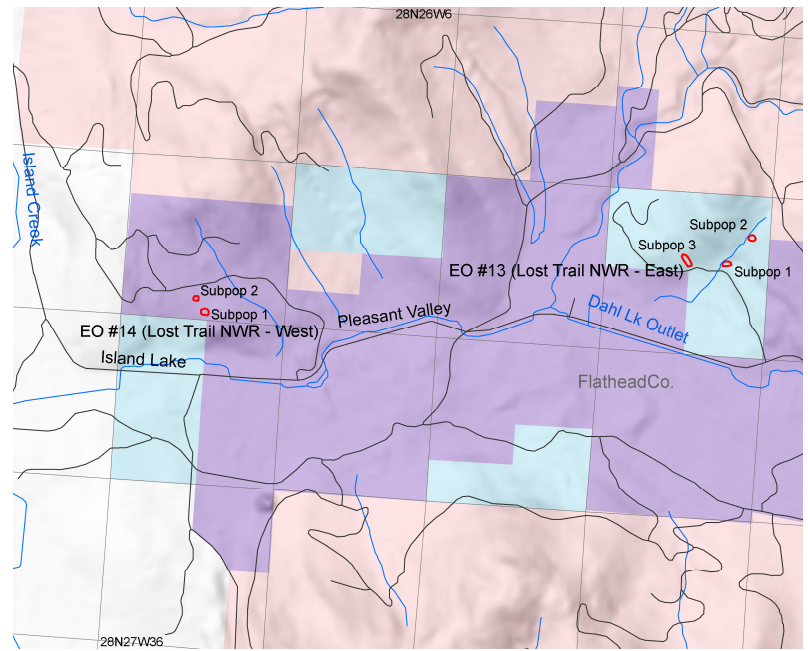

Figure 30. Map of EO \#14 with nearby EO \#13.

Vegetation

Associated Dominant Species: Festuca scabrella, Festuca idahoensis, Stipa richardsonii, Elymus spicatus, Danthonia intermedia, Stipa nelsonii and Lithospermum ruderale.

Exotic Species: Poa compressa and Phleum pratense (common timothy).

August 22, 2005

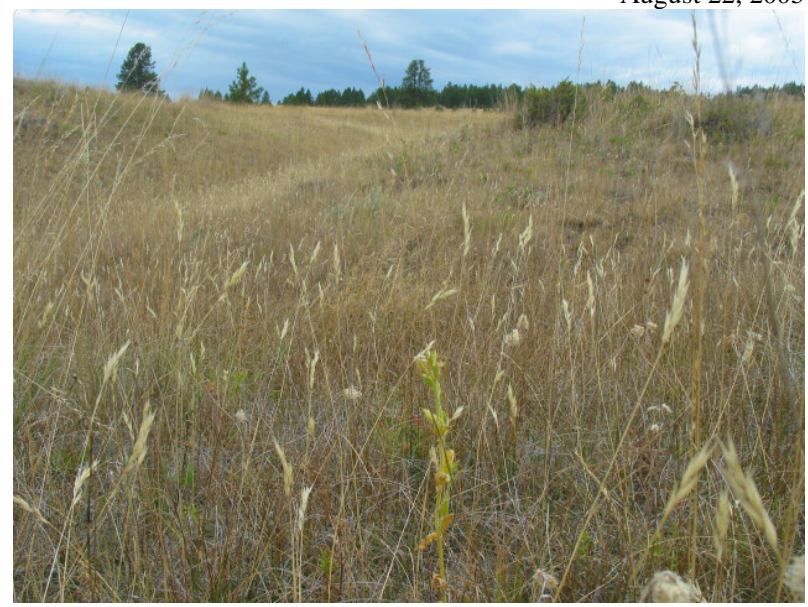

Figure 31. Lost Trail NWR West- EO \#14, subpop. 1.

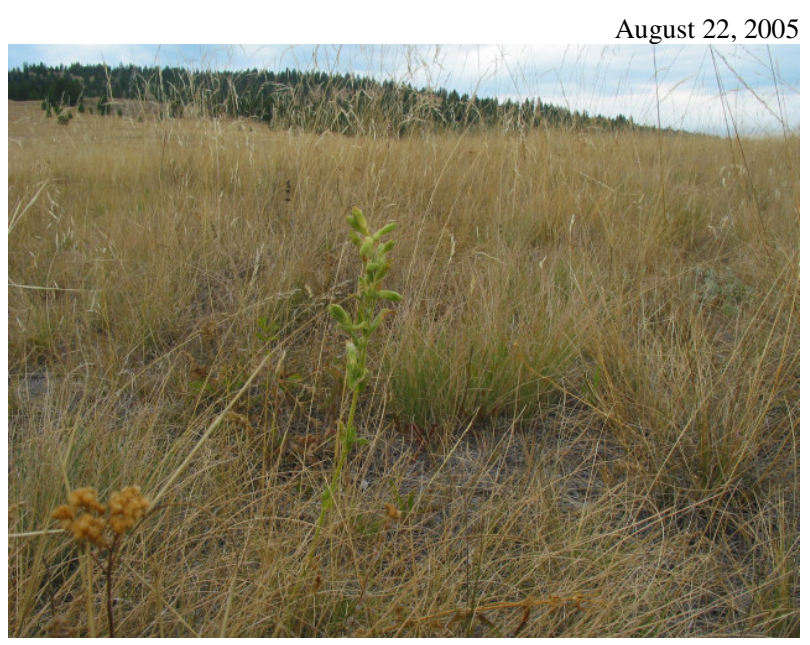

Figure 32. Lost Trail NWR West- EO \#14, subpop. 1.

Survey Data

First Observation: 2002

Last Observation: August 22, 2005

Table 9. Survey data for EO \#14.

\begin{tabular}{|c|c|c|c|}
\hline Year & Total & SP 1 & SP 2 \\
\hline $2002 *$ & 178 & NA & NA \\
\hline 2005 & $\begin{array}{c}11 \text { mature } \\
\text { plants }\end{array}$ & 9 & 2 \\
\hline
\end{tabular}

* Original survey data from the Lost Trail NWR has apparently been lost and associated data files corrupted. Original estimate of 300-350 plants is not verifiable.

This population was apparently discovered in 2002, though original documentation for the occurrence is unavailable. Estimates for this population have been reported to be as high as 350 plants (Hill and Gray 2004), though conversations with Refuge staff place the actual 2002 count at 178 plants. Unfortunately, documentation to support this estimate/count are not available and original data files at the Refuge have been lost and/or corrupted (Verlanic, personal communication, 2005). It is also unclear if the higher estimate may have included the preceding occurrence, EO \#13, which is approximately five kilometers away. More survey work is needed in the area to determine the actual size and extent of the population.

Threats to this occurrence are minimal due in large part to its protected status on the Refuge. Few exotic species are present in the area immediately surrounding the $S$. spaldingii plants, though 
invasive species, including Potentilla recta and Hypericum perforatum, occur in the area.

Three permanent belt transects measuring $15 \mathrm{~m}$ in length were established in subpopulation 1 in 2003 for a demographic monitoring study (Lesica and Crone 2004). Data are not presented here due to the limited survey data available as of this report, though the study should provide meaningful trend data in future years. 


\section{Sullivan Creek - EO \#15}

EO Rank: CD

Rank Date: September 1, 2005

Size: 3 hectares ( 8 ac.)

Counties: Flathead

Ownership: Flathead Indian Reservation and possibly extending onto Plum Creek Timber Company lands

Elevation: $1035 \mathrm{~m}$ to $1140 \mathrm{~m}$

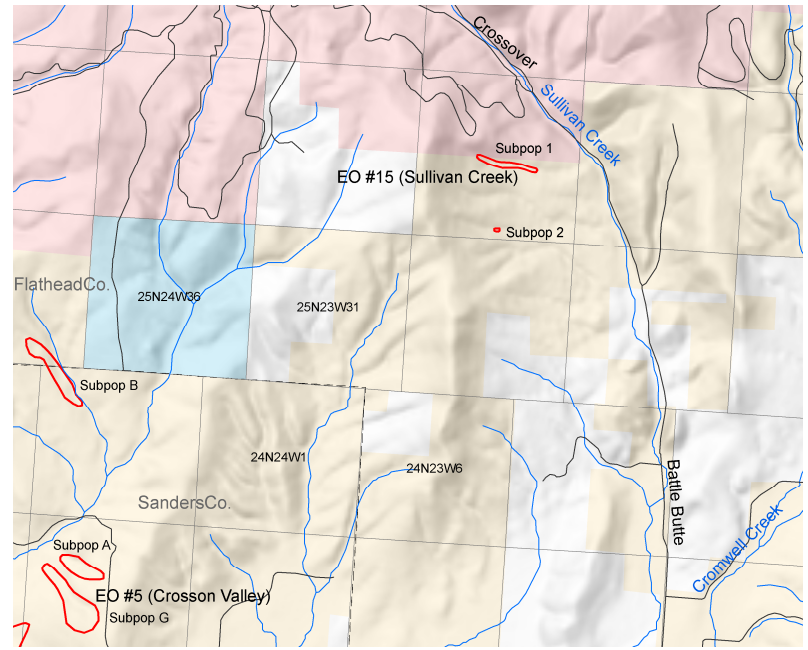

Figure 33. Map of EO \#15 with part of nearby EO \#5.

\section{$\underline{\text { Vegetation }}$}

Associated Dominant Species: Stipa nelsonii, Festuca scabrella, Festuca idahoensis, Monarda fistulosa, Crataegus douglasii (black hawthorn) and Amelanchier alnifolia (serviceberry).

Exotic Species: Frequent exotics are Hypericum perforatum and Bromus tectorum. Occasional exotics include Centaurea maculosa, Poa pratensis and Potentilla recta. Infrequent exotics include Verbascum blattaria and Verbascum thapsus.

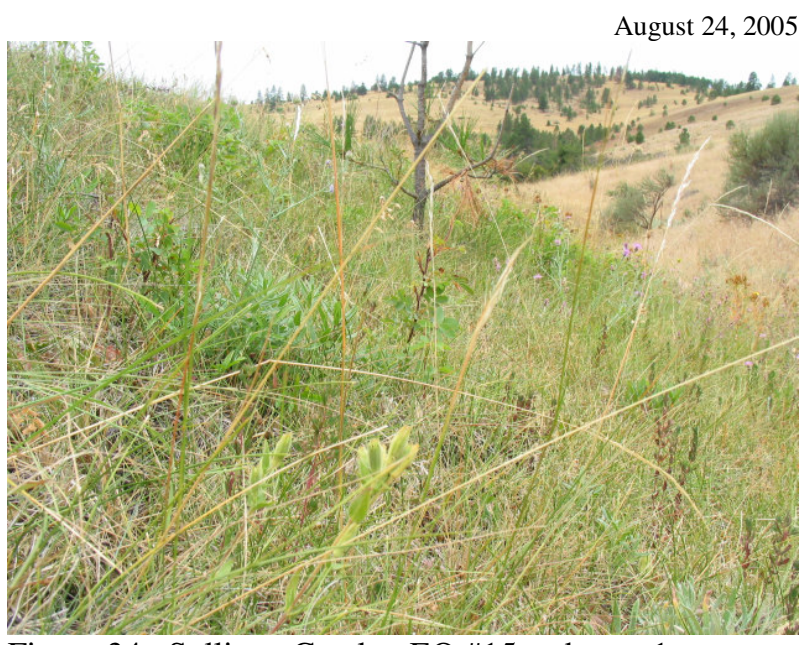

Figure 34. Sullivan Creek - EO \#15, subpop. 1.

\section{Survey Data}

First Observation: August 24, 2005

Last Observation: August 24, 2005

Table 10. Survey data for EO \#15.

\begin{tabular}{|c|c|c|c|}
\hline Year & Total & SP 1 & SP 2 \\
\hline 2005 & $\begin{array}{c}7 \text { mature } \\
\text { plants }\end{array}$ & 6 & 1 \\
\hline
\end{tabular}

This small population was discovered in 2005 . It occurs primarily on the northern end of the Flathead Indian Reservation and possibly extends onto Plum Creek Timber Company lands.

Scattered plants were observed on the northerly aspect of minor draws on an east-facing slope. The site was moderately to heavily grazed by cattle during the survey in 2005. Many weeds occur directly at $S$. spaldingii locations and across the adjacent area, including: Bromus tectorum, Centaurea maculosa, Potentilla recta, Hypericum perforatum, Verbascum thapsus and Verbascum blattaria. A couple, small patches of Linaria dalmatica (Dalmatian toadflax) were also observed on the slope. Associated dominant species were typical of other locations and include Stipa nelsonii, Festuca scabrella, Festuca idahoensis and Monarda fistulosa. A few S. spaldingii plants were observed near the bases of tall, broadleaf shrubs of Amelanchier alnifolia and Crataegus douglasii. The occurrence consists of two small subpopulations that cover an area of three hectares. 
The small size of this population, in conjunction with the moderate to heavy grazing impacts and the prevalence of several invasive weeds, limits the conservation status and long-term viability of this population. However, a single survey does not provide much information about the size of the population or the conservation value of the site. The population may be significantly larger than observed during the 2005 survey, and with proper grazing management and weed control efforts this population may still be of long-term conservation value. Short- and long-term grazing plans for the site are unknown at this time. 
4. Additional Survey Areas: Numerous surveys for Silene spaldingii have occurred since the early 1980's. However, many surveys occurred during dry years when a large percentage of plants were probably dormant. Therefore, future surveys in previously searched areas may still prove fruitful. In general, many areas of suitable habitat near existing occurrences have been searched. Areas as far south as the National Bison Range and grasslands near Polson have been searched by Peter Lesica, as well as habitat in Glacier National Park (Lesica, personal communication, 2005). Surveys in 1988 and 2003 by Montana Natural Heritage Program staff on the Flathead Indian Reservation and in the Eureka area occurred in dry years when plants were mainly dormant. Populations discovered during that time, such as EO \#'s 9 and 10 were observed to have far fewer individuals than observed in a "good" year, such as 2004. In fact, an additional subpopulation (subpopulation $\mathrm{G}$ ) to EO \#5 was observed in 2004 for the first time with 151 mature plants. This provides strong support for surveying areas of potentially suitable habitat in "good years" even though they may have already been searched. For more detailed information on areas that have been searched, please contact the Montana Natural Heritage Program.

In 2005, a few additional areas were searched based on the results of a limited predictive modeling exercise, the details of which are provided in the next section. These surveys resulted in finding two additional populations, EO \#12 - Black Lake and EO \#15 - Sullivan Creek.

\section{F. Habitats}

Silene spaldingii is found in valley and foothill Palouse grasslands in northwest Montana. Sites occur on rolling kettle/drumlin topography, swales, minor draws, and slopes often below treeline or near scattered Pinus ponderosa. Northerly aspects are most common, though $S$. spaldingii does occur on south slopes such as on the Lost Trail National Wildlife Refuge. Known elevations range from $815 \mathrm{~m}$ to $1160 \mathrm{~m}$. Soils are typically moderately deep, silty loams.
Festuca scabrella is the species most commonly associated with $S$. spaldingii occurrences in Montana and usually has the highest cover value. Other gramminoids that are commonly associated include Festuca idahoensis, Stipa richardsonii, Stipa nelsonii, Stipa comata, Koeleria macrantha and Elymus spicatus. Common forbs include Geum triflorum, Geranium viscosissimum, Lithospermum ruderale and Monarda fistulosa.

However, monitoring studies by Lesica (1997) showed that $S$. spaldingii densities are negatively correlated with the density of $F$. scabrella.

Observations at the Wild Horse Island site, where $F$. scabrella density is high and the numbers of $S$. spaldingii plants observed in recent years have declined, appear to support this conclusion. Shrubs are not common at most locations, though Symphoricarpos albus, Rosa woodsii, Amelanchier alnifolia and Crataegus douglasii are all present on at least one site. The only tree species associated with occurrences in Montana is Pinus ponderosa. Vascular plant species' diversity varies widely across the sites in Montana.

Invasive weeds are present at all of the locations, as is typical of Palouse grasslands throughout western Montana. Common invasive weeds that threaten S. spaldingii sites in Montana include Potentilla recta, Hypericum perforatum, Centaurea maculosa and Bromus tectorum. Other weedy species such as Poa compressa, Poa pratensis and Phleum pratense also are common at some locations.

In August of 2005, prior to field sampling, a quick modeling exercise to map predicted habitat for Silene spaldingii was conducted, the results of which were to be used to prioritize field surveys for locating new occurrences during the limited time available. Modeling took place using ArcMap 9.1. Mapped occurrences (EO \#'s 1, 2, 3, 4, 5, 8, 9, 10 and 11) were overlain with several GIS layers. After suitable attributes were identified from each layer, the identified polygons from each layer were intersected to form the predicted habitat layer.

GIS layers utilized and their attributes identified as suitable when used as mentioned above include: 
1. Montana Geology Layer

Alluvium- Sedimentary

Sedimentary, Belt Series - Pricard Formation

Sedimentary, Belt Series - Ravalli Group

Tertiary sedimentary rocks, undifferentiated

2. STATSGO Soils Layer

Map units: MT044, MT136, MT202, MT243

and MT391.

3. Annual Precipitation Layer

15-22 inch precipitation zones

\section{National Land Cover Data (NLCD) Layer Grasslands/Herbaceous}

Areas of annual precipitation and soils identified as "suitable" restricted potential habitat to areas in the Flathead, Mission and Tobacco Plains and west. The model did not flag areas in or around the Bob Marshall Wilderness Complex or Glacier National Park as suitable based on either the soils or precipitation alone. However, these areas have been mentioned in previous reports as areas that should be searched for $S$. spaldingii.
Use of the NLCD layer to identify grasslands led to some over-predicting of suitable habitat due to some clearcuts being classified as grassland types. Despite the over-predictions, the NLCD layer more accurately classified grasslands compared to the Montana GAP data layer, which classifies many clearcuts as grasslands. Prior to conducting fieldwork, modeling results were visually compared with digital orthophotographs to quickly eliminate areas that were obviously not suitable, such as clearcuts.

Figure 35 displays the areas predicted as suitable habitat at a coarse scale. Two new populations were located based on the model predictions, EO \#12 near Eureka and EO \#15 near Niarada. Additionally, the area around Lost Trail NWR was predicted as suitable even though those populations were not used in the assessment. The two new populations discovered as a result of this effort were only two of approximately five localized areas that were searched in 2005 . Refined mapping efforts, including the use of topographic indices and further survey efforts in areas identified in the current product, have the potential to lead to further $S$. spaldingii discoveries. 


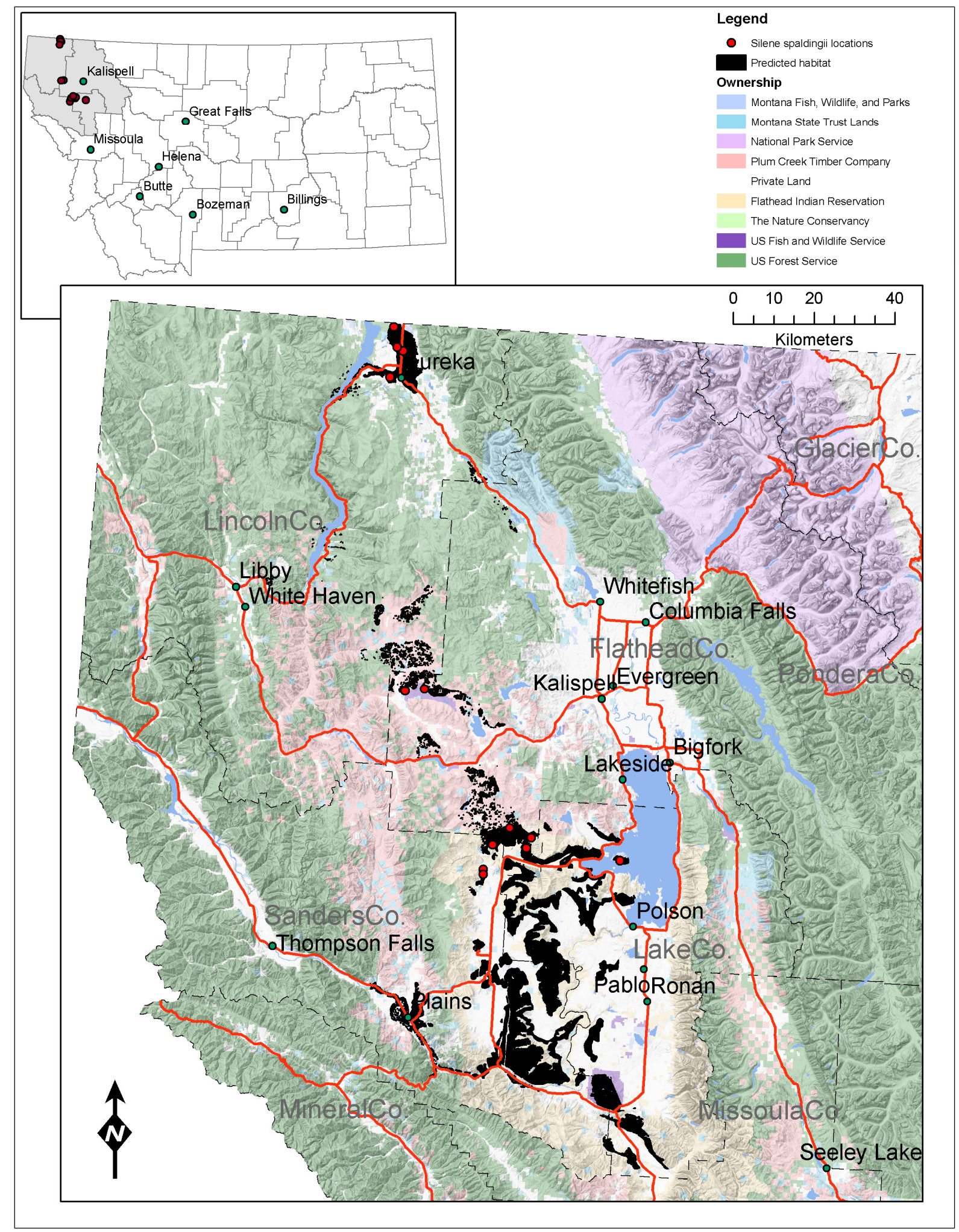

Figure 35. Results of predictive habitat modeling for Silene spaldingii using geology, STATSGO soils, annual precipitation and vegetation (NLCD) data layers. 


\section{G. Land Ownership}

Ownership and management of Silene spaldingii sites in Montana is simplified by the fact that the seven highest quality sites fall under four broad ownership categories (Table 11). Three occurrences are located on state lands. The Montana Department of Fish, Wildlife and Parks manages one and two are located on State Trust Lands managed by the Montana Department of Natural Resources. The Dancing Prairie Preserve, which contains the largest population, is owned by The Nature Conservancy and actively managed to maintain and protect the species. The Confederated Salish and Kootenai Tribes manage two populations that occur on the Flathead Indian Reservation and the remaining population occurs on land now managed as part of the Lost Trail National Wildlife Refuge. Three of these populations are contained on land directly managed for their conservation value and as such have perhaps the best chance for beneficial management options. Four of the remaining EO's are on private lands with two already believed to be extirpated.

Table 11. Ownership of S. spaldingii by EO Rank, excluding historical occurrences.

\begin{tabular}{|l|c|c|c|c|c|c|}
\hline Ownership & A & B & C & CD & X? & Tot. \\
\hline Private & & & 1 & 1 & 2 & 4 \\
\hline State & & 3 & & & & 3 \\
\hline TNC & 1 & & & & & 1 \\
\hline Tribal & 1 & 1 & 1 & 1 & & 4 \\
\hline USFWS & & 1 & & & & 1 \\
\hline Totals & 2 & 5 & 2 & 2 & 2 & 13 \\
\hline
\end{tabular}

\section{H. Threats}

Several threats to Silene spaldingii and its habitat have been recognized, observed and/or documented in the field or in publications by numerous sources across its range. These known and potential threats are well documented and summarized by Hill and Gray (2004) in the range-wide "Conservation Strategy for Silene spaldingii" (available on-line at http://fishandgame.idaho.gov at the time of this report). In Montana, several of these threats and associated detrimental impacts to $S$. spaldingii are evident, such as those posed by invasive weeds, livestock grazing, development, and the effects of fire exclusion. Others are not as directly evident, though are suspected potential problems, including small population sizes and associated genetic bottlenecks, and loss of pollinators in fragmented populations (Barrett and Kohn 1991, Hill and Gray 2004, Lesica and Heidel 1996). Several of the more important and/or documented known and potential threats are discussed below.

1. Invasive Species: Invasive weeds have most likely become more prevalent in and around many of the sites in the past two decades since the first surveys for $S$. spaldingii were initiated in Montana. Invasive weeds have been documented at, or directly adjacent to, all $S$. spaldingii populations in the state. However, little data exist to make any quantitative assessments on the impacts invasive weeds have on S. spaldingii. Still, it is widely known that weed invasion is a serious threat to the long-term condition and functioning of western grasslands. Invasive weeds degrade habitat by altering species composition and structure, changing soil water and nutrient dynamics and by out-competing native species (Brooks etal. 2004, D'Antonio and Vitousek 1992, Mack and D' Antonio 1998, Olson 1999, Pimentel etal. 2004). Invasive weeds, including several state listed noxious weeds in Montana, such as Centaurea maculosa, Hypericum perforatum, Potentilla recta, Euphorbia esula and Linaria dalmatica are a serious threat to sites supporting $S$. spaldingii (MT Dept. of Agriculture 2003). In addition, many other wildland weeds are problematic in western Montana grasslands and are already present in or near several S. spaldingii sites, including Bromus tectorum, Poa pratensis and Poa compressa. Caplow (2002) observed lower vigor of $S$. spaldingii with greater weed cover at Fairchild AFB, Washington. In Montana, S. spaldingii was notably absent in dense patches of weeds scattered throughout the Hog Heaven Range occurrence during the 2004 survey (Mincemoyer personal observation). Weeds may also directly compete for pollinators with $S$. spaldingii. Heidel and Lesica (1996) observed bumblebees switching to Hypericum perforatum flowers after visiting a $S$. spaldingii flower one-third of the time at a site in Idaho.

Invasive species dominate several areas surveyed for $S$. spaldingii in Montana and predicted as 
suitable habitat in the modeling exercise. Examples include land managed by the Montana Department of Fish, Wildlife and Parks northwest of Eureka. This area is dominated by the exotic grass Bromus inermis, which is used extensively as a pasture grass. Another drainage just eastnortheast of the Crosson Valley population is severely weeded by Centaurea maculosa, Bromus tectorum and other species. It is unknown if these areas ever supported $S$. spaldingii prior to becoming dominated by non-native species.

2. Livestock Grazing: Grazing impacts to grassland communities and the associated negative effects to Silene spaldingii are discussed in detail in Hill and Gray (2004). In brief, livestock grazing causes soil disturbance that may promote the establishment and spread of invasive weeds. Livestock preferentially graze on more palatable bunchgrasses and forbs leaving the less palatable species, which in many cases are weeds. Livestock also act as vectors for seed dispersal, transferring weed seeds across and between sites. Finally, grazers may directly negatively impact $S$. spaldingii plants through trampling, direct consumption of flowerheads, and by negatively impacting pollinator habitat, all resulting in decreased seed production (Hill and Gray 2004).

Livestock (mainly cattle) grazing is a currently known use within five $S$. spaldingii occurrences. In addition, severe impacts associated with llama grazing are believed to have caused or contributed to the likely extirpation of $S$. spaldingii at two sites in Montana recently. Specific grazing management on the four occurrences on the Flathead Indian Reservation and at the Black Lake occurrence on state land is not known. However, the Confederated Salish and Kootenai Tribe did alter the grazing lease at one $S$. spaldingii occurrence in 1995 to benefit the plant. The lease terms were altered to allow grazing only in the late fall season when less impact to the plant was likely to occur (Matt 2000).

3. Development: Development is currently only a direct threat to the Roosville occurrence. However, it is anticipated that development in the Tobacco Plains will likely impact populations beyond the Roosville EO. Habitat fragmentation due to development will isolate the Dancing Prairie population, the Indian Creek Road population and the Black Lake population. This will reduce or hamper potential long-term management options such as burning, and will also decrease habitat for the main pollinator, the bumblebee (Bombus fervidus). Fragmentation will also decrease the chance of gene flow between populations, isolating them further and potentially leading to increased amounts of in-breeding depression.

4. Natural Disturbances: Continued drought or other long-term climatic changes have the potential to detrimentally impact $S$. spaldingii populations. Drought appears to increase the number of $S$. spaldingii plants that remain summer dormant. This results in a reduction in seed production by directly decreasing the number of flowers available for pollination. Drought may also hasten the spread of invasive weeds and change fire frequencies. Though increased fire may be beneficial in some cases, it can also negatively impact seed production and further the spread of some weeds (Hill and Gray 2004).

A decrease in fire frequency appears to be having a detrimental impact to a few of the S. spaldingii occurrences in Montana. Lesica (1999) has shown that $S$. spaldingii responds favorably to spring and fall burns at Dancing Prairie Preserve, and grasslands in northwest Montana evolved with a frequent fire regime (Dorey 1979, Barrett and Arno 1982). Small population sizes observed at Black Lake, Wild Horse Island and Cromwell Creek appear to be due, in part, to a build-up of litter and competition for resources from Festuca scabrella. This build-up of litter appears to inhibit the growth and reproduction of $S$. spaldingii, and most likely is partially responsible to declines or the small population sizes currently observed at these sites. Management that mimics natural fire frequencies may be necessary to spur growth and expansion of these populations. However, fires that are too frequent may have the reverse effect and actually threaten populations by reducing seed production, killing $S$. spaldingii plants and by opening up the site for weeds to invade.

The genetics of $S$. spaldingii were discussed earlier. The Dancing Prairie population has already been documented to have higher 
percentages of homozygotes and in-breeding depression than populations studied in other sites. Increased fragmentation and smaller numbers of flowering individuals due to other causes may increase in-breeding depression and genetic drift. Small populations are already prone to problems associated with genetic factors and decreased visitations by pollinators (Barrett and Kohn 1991,
Hill and Gray 2004). All of these factors, when taken together, have the potential to cause a downward trend in already small populations.

For a detailed discussion of other potential threats to Silene spaldingii in Montana and range-wide see Hill and Gray 2004. 


\section{ASSESSMENT AND RECOMMENDATIONS}

\section{A. General Assessment of Trends and Status}

The lack of good, systematic survey data over many years hampers a discussion of population trends in Montana. Dormancy of plants during surveys also has a substantial impact on determining population sizes and trends, since most survey data collected over the years do not adequately measure or represent the population. At Dancing Prairie, Lesica (1997) observed the population to be stable when analyzing demographic monitoring data from 1989-1994. The Wild Horse Island population appears to be declining based on survey data collected over two decades and declines are further supported by the demographic monitoring data presented in Figure 13. This decline is likely due to increased densities of Festuca scabrella and the lack of disturbance such as fire over what has likely been several decades. The small occurrences of EO \#'s 3 and 4 are believed to be recently extirpated or at a minimum their habitat is probably irreversibly damaged. The Crosson Valley occurrence has recently been documented to be substantially larger than previously observed. It is unclear if this is due to favorable changes in grazing management at parts of the site or whether this is an artifact of more comprehensive surveys during a "good" year or some combination of these factors. The Roosville occurrence is almost certainly declining due to residential development and weed invasion, though only limited survey data exist for these sites. The Cromwell Creek site appears to be stable based on limited survey data. Weeds currently are not negatively affecting the site, though competition from dense Festuca scabrella may be having a negative effect. Observations at the Hog Heaven Range population noted substantially more plants than the 1988 survey, though this is probably an artifact of drought during the initial survey. Additionally, this site is impacted by several invasive weeds and one would expect a negative impact as a result of the degradation of the site over the long-term. Little can be said as to trends at the Indian Creek Road occurrence as it has not been visited since 1989 and the landowner denied access in 2003. The condition of the habitat at this site is unknown, as is whether the population is still extant. The remaining occurrences (EO \#'s 12-15) have been discovered recently and it is too early to make determinations about trends for those populations. However, all sites except the Sullivan Creek site are in good bunchgrass habitat with few weeds. Observations at the Sullivan Creek site in 2005 noted problems with several invasive weeds and that the area was heavily grazed by cattle, so longterm trends would not be expected to be positive under this scenario. The small population at Black Lake discovered in 2004, though in good fescue habitat, is potentially being negatively impacted by the density of Festuca scabrella at the site.

Results of surveys in 2004 and 2005 provided positive data by documenting two new occurrences, observing three new subpopulations, and documenting two occurrences to be much larger than previously recorded. In contrast, two occurrences are believed to be extirpated or severely degraded and the Roosville area is being directly impacted by development and weeds that substantially decrease the probability of long-term viability of that population.

Total numbers of $S$. spaldingii in Montana are not apparent due to the sampling issues mentioned previously. A minimum estimate of 10,000 plants is probably conservative based on the population estimate for the Dancing Prairie population. Extrapolating dormancy rates measured by Lesica (1997) at Dancing Prairie across the other Montana populations may provide a better estimate of the $S$. spaldingii population in the state. Estimates of the number of individuals are provided in Table 12. This analysis provides a minimum estimate of approximately 12,000 plants and an upper estimate of 43,000 plants. Lesica (2003) previously estimated 10,000 plants as a minimum and 50,000 for an upper limit in Montana. 
Table 12. Estimates of Montana S. spaldingii population size at each occurrence and statewide. Numbers are extrapolated from most recent observation data (Actual) and increased by dormancy rates observed by Lesica (1997) to provide minimum, maximum and mean estimates of population sizes. Figures are rounded to prevent the impression that precise numbers are known.

\begin{tabular}{|c|c|c|c|c|}
\hline EO\# & Actual & Minimum & Mean & Maximum \\
\hline 01 & 10,000 & 11,200 & 17,000 & 38,500 \\
\hline 02 & 22 & 25 & 40 & 85 \\
\hline 05 & 651 & 730 & 1,100 & 2,500 \\
\hline 08 & 40 & 45 & 70 & 155 \\
\hline 09 & 27 & 30 & 45 & 100 \\
\hline 10 & 173 & 195 & 290 & 670 \\
\hline 11 & 23 & 25 & 40 & 90 \\
\hline 12 & 18 & 20 & 30 & 70 \\
\hline $13+14$ & 178 & 200 & 300 & 680 \\
\hline 15 & 7 & 8 & 12 & 25 \\
\hline Totals & 11,100 & 12,500 & 18,900 & 42,900 \\
\hline
\end{tabular}

A semi-quantitative assessment was conducted using the approaches outlined by Regan, Master and Hammerson (2004) and adapted by the Montana Natural Heritage Program for use in ranking animal species of concern (MTNHP 2004). Both of these similar assessment methods assign points to factors such as number of occurrences, population size, area or range extent, trends and threats. Some factors may not be used if data are missing or an estimate of the parameter is too uncertain. The points from the most pertinent criteria are added together to form a final score for the species. Lastly, a Heritage rank of 1 to 5 at a state level is assigned based on the final score. The ranking criteria and scores assigned for the $S$. spaldingii state assessment are found in Table 13 using the two slightly different scoring methods.

Table 13. Ranking factors and assigned scores for the $S$. spaldingii Montana status assessment. The first point allocation numbers are those used in the scoring method of Regan, Master and Hammerson (2004) and the second point scores are those used in the method outlined by the MTNHP State rank criteria for animal species of concern. See Regan, Master and Hammerson (2004) and MTNHP (2004) for a complete discussion of the methodologies.

\begin{tabular}{|c|c|c|c|}
\hline Factor & Parameter Estimate & Category & Point Allocation \\
\hline \# of Occurrences & $6-20$ & B & 2/Not used \\
\hline Condition of Occurrences & Few (4-12) with good or excellent viability & C & $0 /$ Not used \\
\hline Population Size & $10,000-100,000$ plants & F & $0 / 0$ \\
\hline Area of Occupancy & $0.4-4 \mathrm{~km}^{2}(100-1,000$ acres $)$ & B & Not used/-0.75 \\
\hline Geographic Range & $100-250 \mathrm{~km}^{2}(40-100$ sq. miles $)$ & B & Not used/Not used \\
\hline Long-term Trend & Relatively stable $(+-25 \%$ change $)$ & E & 0 \\
\hline Short-term Trend & Stable & E & \multirow{2}{*}{$-0.75 /-0.75$} \\
\hline Threats-Severity & Moderate & B & Not used/Not used \\
\hline Threats-Scope & Moderate & B & Not used/Not used \\
\hline Threats-Immediacy & High & B & $0 / 3.5$ \\
\hline Intrinsic Vulnerability & Moderately vulnerable & Initial Point \\
\hline Environmental Specificity & Narrow with key requirements common & Score & Ration \\
\hline & & Rank & S1/S2 \\
\hline
\end{tabular}

The assignment of the threat attributes of severity, scope and immediacy is a mostly subjective process and, as such, is open to interpretation. The most apparent threats to the viability of the species appear to be from loss of habitat due to weed invasion, impacts associated with grazing and negative impacts associated with fire exclusion. Additionally, most occurrences are small, isolated populations which may result in future genetic bottlenecks and reproductive problems.

The Montana Natural Heritage rank for this species will remain at $\mathrm{S} 1$ - at high risk because of extremely limited and potentially declining numbers, extent or habitat, making it vulnerable to extirpation in the state. 


\section{B. Conservation and Follow-up Recommendations}

The conservation strategy for Silene spaldingii in Montana focuses on several primary elements: protecting existing sites, improving habitat condition, rebuilding populations, mitigating impacts of invasive weeds and grazing, and increasing monitoring and survey efforts. Additional studies are needed on site-specific pollinators in Montana, as are studies of the genetics of $S$. spaldingii within Montana and range-wide. In Montana, plants from all four geographic locations (Tobacco Plains, Lost Trail area, Niarada area and Wild Horse Island) should be included in conservation and research efforts. Also, though not directly related to the conservation of $S$. spaldingii itself, more basic research on weed control measures is needed.

1. Conservation and Habitat Protection: The most basic and underlying strategy for conservation of the species in Montana and range-wide is to protect known populations and associated habitat. Opportunities for beneficial management in Montana should be high since the majority of known populations in Montana are on lands administered by state or federal agencies, the Confederated Salish and Kootenai Tribes or The Nature Conservancy. However, development directly threatens the Roosville population and has the potential to impact the Dancing Prairie, Indian Creek Road and Black Lake occurrences by further isolating them from neighboring occurrences and habitat, resulting in decreased pollinators and management options, such as the use of prescribed fire. It is recommended that populations in all four of the geographic areas (Tobacco Plains, Lost Trail area, Niarada area and Wild Horse Island) be protected, as well as any populations discovered in other geographic areas.

Recommended actions include:

a. The protection of land, by purchase or through voluntary conservation easements, of sites known to support $S$. spaldingii and associated grassland habitat in and around Eureka and the Tobacco Plains. This would protect the known occurrences from development and maintain grassland habitat in the area, thus preventing or reducing the isolation of populations caused by development. Protection of grassland habitat in the area also leaves open the possibility of establishment of new $S$. spaldingii occurrences to offset those already lost, or soon to be lost, to development.

b. A special conservation designation for sites located on the Flathead Indian Reservation and on State Trust lands should be established. This designation would highlight the importance of these areas and provide some degree of resource protection against unsuitable management options or potential future development.

\section{Mitigation of threats:}

Weed control: Control of invasive weeds at all $S$. spaldingii sites is vital to the long-term survival of the species. The use of varied and integrated strategies for control and prevention of the spread of invasive species will be necessary. Varied weed control methods will be needed and may include the selective use of herbicides, bio-control agents, hand-pulling as well as other methods. It is recognized that any treatment option is not without risks and side-effects. Caution is urged in the use of any individual or combination of control measures. One example of an un-intended effect of the use of a bio-control agent for knapweed is documented by Ortega, Pearson and McKelvey (2004). However, it is widely recognized that "noaction" is not a legitimate strategy in the control of invasive species. This report does not advocate or discourage any particular weed control method. Instead, a wise and informed, as well as timely, decision-making process before any measures are implemented is recommended.

Grazing management: It is widely regarded that livestock grazing has direct and indirect negative impacts on $S$. spaldingii and its habitat. Cattle are the primary grazers at sites in Montana and contribute to the spread of weeds which degrade the bunchgrass habitats occupied by $S$. spaldingii. Cattle tend to favor many of the more palatable native bunchgrasses and forbs over weedy species that typically will then increase in abundance.

Recommended actions for mitigation of the negative impacts associated with grazing include 
a. The exclusion of livestock from sites supporting

$S$. spaldingii through the use of fencing and exclosures, or,

b. Alternating each year of grazing with one year of rest; allowing grazing only from the fall through early spring to minimize direct impacts to $S$. spaldingii plants and pollinators; and/or by varying the timing of grazing so it does not occur at the same time each year.

Monitoring should be conducted to evaluate the effects of changes in grazing management.

3. Habitat Condition and Fire-use: The changes associated with grassland succession due to fire exclusion appear to have negative impacts on $S$. spaldingii survival and reproduction. Fire itself may have a positive influence on the phenological, biological, and reproductive processes and growth of $S$. spaldingii (Lesica 1999). Fire has most likely been excluded for several decades from some populations, resulting in dense bunchgrass communities with higher amounts of litter build-up than occurred historically. Re-introduction of fire to the Wild Horse Island population, and secondarily to the Black Lake occurrence, is recommended to help reverse the suspected downward trend at these sites. Collection of pre- and post-fire monitoring data similar to the methods used by Lesica (1999) will be key to determining success. If burning is deemed beneficial, plans should be implemented by the managing agency to continue the use of periodic fire at the site. Fire, as with any management tool, should be used cautiously so as not to detrimentally affect $S$. spaldingii or its pollinators (Lesica and Heidel 1996).

4. Monitoring and Surveys: Surveys for $S$. spaldingii in Montana are considered to be incomplete, with much suitable habitat remaining to be surveyed during "good" years. In particular, suitable areas identified in the modeling effort on the Flathead Indian Reservation and the National Bison Range should receive a high priority for surveys. Additionally, suitable habitat near existing occurrences in the Lost Trail NWR area should be searched. Areas of remaining habitat around the greater Columbia Falls area should also be searched to try and re-locate the historical occurrence.

Increased monitoring of $S$. spaldingii populations on the Flathead Indian Reservation, as well as the new occurrence on state land near Black Lake, is recommended. Monitoring should include, at a minimum: counts of $S$. spaldingii observed, observations of pollinator visits, measures of abundance for all invasive species observed, as well as other threats, activities and management observed at or adjacent to the site. Photo documentation of the site should be included during every visit.

A further attempt at a site visit to the Indian Creek Road occurrence is recommended. Determination of land ownership of the site and permission by that landowner will be needed before a survey can be conducted. If the survey effort proves positive, strategies for beneficial management should be explored.

Continuation of the demographic monitoring initiated by Lesica at Lost Trail NWR, Dancing Prairie Preserve and Wild Horse Island is recommended. Data measuring the response to any management action or natural disturbances will help improve management and increase the understanding of the species' biology.

5. Population Size: Populations at four to six of the known locations are probably less than 100 individuals each. This presents significant challenges and obstacles to the long-term viability of these occurrences. Management practices that may prove beneficial to the survival and growth of $S$. spaldingii at these sites should be implemented, and the effects of any actions thoroughly documented and monitored. Besides the use of prescribed fire, supplementing populations with additional $S$. spaldingii grown from seed collected at the target site should be investigated.

Supplementing a population with plants (or seeds) raised from seed from a nearby occurrence is a strategy that may also need to be considered to increase the exchange of genetic material between isolated occurrences. Without exchange of some genetic material between isolated occurrences, the viability of small populations is likely to decrease due to the negative effects associated with high 
levels of homozygosity and in-breeding depression. The Wild Horse Island population is a prime candidate due to its small size, isolated nature, state-management and lack of invasive species.

6. Research: Studies of $S$. spaldingii pollinators in Montana have only taken place at Dancing Prairie. Additional studies at other occurrences are needed to document if the bumblebee is the only pollinator of importance and to quantify visitation rates. A pollinator study at a small, isolated population such as Wild Horse Island in conjunction with additional genetic data may help answer questions concerning the viability of small populations. Further study of the Wild Horse Island population should determine if the apparent downward trend is real and provide insight as to the cause or causes.

Only one limited study of the genetics of $S$. spaldingii has been completed (Baldwin and Brunsfeld 1995). Additional studies that include more Montana material from several occurrences are needed to elucidate genetic variability within and among populations. This information is needed in the larger context of the species' rangewide distribution. Data from such a study are vital to determining the genetic importance of individual populations and their conservation value, as well as the amount of gene flow between populations.

Genetic data should also be useful in determining guidelines for the use of seed from one population in supplementing or establishing additional populations.

Additional demographic data, in conjunction with the genetic and pollinator data, may also help determine minimum population sizes and whether supplementing smaller populations will be needed to continue their existence.

The preceding conservation recommendations are those deemed most significant to helping ensure the continued existence and viability of $S$. spaldingii in Montana. Many of these recommendations, as well as additional ones, are voiced by Hill and Gray (2004) with added supporting documentation. 


\section{Literature Cited}

Baldwin, C. T. and S. J. Brunsfeld. 1995. Preliminary genetic analysis of Silene spaldingii (Spalding's catchfly), a candidate threatened species. Wildland Plant Ecogenetics Cooperative, University of Idaho and the Montana Natural Heritage Program, Helena, MT. 8 pp. + appendices.

Barrett, S. W. and S. F. Arno. 1982. Indian fires as an ecological influence in the Northern Rockies. Journal of Forestry 80: 647-651.

Barrett, S. C. H. and J. R. Kohn. 1991. Genetic and evolutionary consequences of small population size in plants: Implications for conservation. Pages 3-30 In D. A. Falk and K. E. Holsinger, editors. Genetics and conservation of rare plants. Oxford University Press, New York, New York. 283 pp.

Brooks, M. L., C. D'Antonio, D. Richardson, J. Grace, J. Keeley, J. DiTomaso, R. Hobbs, M. Pellant and D. Pyke. 2004. Effects of invasive alien plants of fire regimes. BioScience 54(7): 677-688.

Caplow, F. 2002. Annual report for Spalding's catchfly (Silene spaldingii) on Fairchild AFB, Washington. Washington State Department of Natural Resources, Natural Heritage Program, Olympia, Washington. 11 pp. + appendices.

D'Antonio, C. M. and P. M. Vitousek. 1992. Biological invasions by exotic grasses, the grass/fire cycle, and global change. Annu. Rev. Ecol. Syst. 23: 63-87.

Dolan, R. W. 1994. Patterns of isozyme variation in relation to population size, isolation and phytogeographic history in royal catchfly (Silene regia: Caryophyllaceae). Amer. J. Bot. 81(8): 965971.

Dorey, R. J. 1979. A fire history investigation and the effects of fire exclusion on a ponderosa pine forest in southeastern British Columbia. B.S. thesis, University of British Columbia, Vancouver.
Dorn, R.D. 1984. Vascular plants of Montana. Mountain West Publishing, Cheyenne, Wyoming. $276 \mathrm{pp}$.

Hill, J. L. and K. L. Gray. 2004. Conservation strategy for Spalding's catchfly (Silene spaldingii Wats.). Idaho Department of Fish and Game, Conservation Data Center, Boise, Idaho. 153 pp. + appendices.

Hitchcock, C. L., A. Cronquist, M. Ownbey and J. W. Thompson. 1964. Vascular plants of the Pacific Northwest, Part 2: Salicaceae to Saxifragaceae. University of Washington Press, Seattle, Washington. 597 pp.

Lesica, P. 2004. Monitoring population trend of Silene spaldingii on Dancing Prairie Preserve 2004 Progress Report. Report to the Nature Conservancy, Montana Field Office, Helena, MT. $5 \mathrm{pp}$.

Lesica, P. 2003. Comments on the draft conservation strategy for Silene spaldingii from The Nature Conservancy of Montana - 11/15/2003. Helena, MT. 6 pp.

Lesica, P. 1999. Effects of fire on the demography of the endangered, geophytic herb Silene spaldingii (Caryophyllaceae). Amer. J. Bot. 86(7): 996-1002.

Lesica, P. 1997. Demography of the endangered plant, Silene spaldingii (Caryophyllaceae) in northwest Montana. Madroño 44(4): 347-358.

Lesica, P. 1993. Loss of fitness resulting from pollinator exclusion in Silene spaldingii (Caryophyllaceae). Madroño 40(4): 193-201.

Lesica, P. 1988. Germination requirements and seedling biology of Spalding's catchfly (Silene spaldingii). Unpublished report on file at the Montana Natural Heritage Program, Helena, MT. $2 \mathrm{pp}$. 
Lesica, P. 1986. Monitoring of a population of the rare plant Silene spaldingii on Wildhorse Island. Unpublished report on file at the Montana Natural Heritage Program, Helena, MT. 3 pp.

Lesica, P. and E. Crone. 2004. Demographic monitoring of Silene spaldingii at four sites in Montana and Washington. Unpublished report. Missoula, Montana. 5 pp.

Lesica, P. and B. Heidel. 1996. Pollination biology of Silene spaldingii. Unpublished report to The Nature Conservancy, Helena, MT. Montana Natural Heritage Program, Helena, MT. 16 pp.

Lesica, P. and B. M. Steele. 1994. Prolonged dormancy in vascular plants and implications for monitoring studies. Natural Areas Journal 14: 209212.

Mack, M. C. and C. D'Antonio. 1998. Impacts of biological invasions on disturbance regimes. Trends in Ecology and Evolution 13:195-198.

Mack, R. N. and J. N. Thompson. 1982. Evolution in steppe with few large, hooved mammals. American Naturalist 119: 757-773.

Matt, D. F. 2000. Tribal comments to proposed listing of Spalding's catchfly as threatened pursuant to the Endangered Species Act. Letter to the U.S. Fish and Wildlife Service, Boise, ID. January 27, 2000. The Confederated Salish and Kootenai Tribes, Pablo, MT. 4 pp.

Menges, E. S. and W. Dolan. 1998. Demographic viability of populations of Silene regia in Midwestern prairies: relationships with fire management, genetic variation, geographic location, population size and isolation. Journal of Ecology 86: 63-78.

Montana Department of Agriculture. 2003.

Montana Noxious Weeds List. On-line: http://agr.state.mt.us/weedpest/noxiousweedslist2.a $\mathrm{sp}$

Montana Natural Heritage Program. 2004. State rank criteria for animal species of concern. Online: http://nhp.nris.state.mt.us/animal/index.html.
NatureServe. 2005. NatureServe Explorer: An online encyclopedia of life [web application]. Version 4.5. NatureServe, Arlington, Virginia. Available at: http://www.natureserve.org/explorer. (Accessed: September 11, 2005).

Nei, M. 1978. Estimation of average heterozygosity and genetic distance from a small number of individuals. Genetics 89: 583-590.

Olson, B. E. 1999. Impacts of noxious weeds on ecological and economic systems. pp 4-18. In: R.L. Sheley and J. K. Petroff, editors. Biology and management of noxious rangeland weeds. Oregon State University Press. Corvallis, Oregon. 438 pp.

Ortega, Y. K., D. E. Pearson and K. S. McKelvey. 2004. Effects of biological control agents and exotic plant invasion on deer mouse populations. Ecological Applications 14(1): 241-253.

Pimentel , D., R. Zuniga and D. Morrison. 2005. Update on the environmental and economic costs associated with alien-invasive species in the United States. Ecological Economics 52(3): 273-288.

Regan, T. J., L. L. Master and G. A. Hammerson . 2004. Capturing expert knowledge for threatened species assessments: a case study using NatureServe conservation status ranks. Acta Oecologica 26: 95-107.

USDA, NRCS. 2005. The PLANTS Database, Version 3.5 http://plants.usda.gov. Data compiled from various sources by Mark W. Skinner. National Plant Data Center, Baton Rouge, LA 70874-4490 USA.

U.S. Fish and Wildlife Service. 2001. Endangered and threatened wildlife and plants; Final rule to list Silene spaldingii (Spalding's catchfly) as threatened. Federal Register 66(196): 5159851606.

U.S. Fish and Wildlife Service. 2000. Endangered and threatened wildlife and plants; Notice of proposed critical habitat determination for the plant Silene spaldingii (Spalding's catchfly) and reopening of comment period. Federal Register 65(79): 21711-21713. 
U.S. Fish and Wildlife Service. 1999. Endangered and threatened wildlife and plants; Proposed threatened status for the plant Silene spaldingii (Spalding's catchfly). Federal Register 64(232): 67814-67821.

U.S. Fish and Wildlife Service. 1998. Endangered and threatened wildlife and plants; 90-day finding for a petition to list Silene spaldingii (Spalding's catchfly) as endangered or threatened. Federal Register 63(220): 63661-63662.

Westerbergh, A. and A. Saura. 1994. Genetic differentiation in endemic Silene (Caryophyllaceae) on the Hawaiian Islands. Amer. J. Bot. 81(11): 1487-1493. 


\section{Appendix A. Global/State RANK Definitions}




\section{HERITAGE PROGRAM RANKS}

The international network of Natural Heritage Programs employs a standardized ranking system to denote global (range-wide) and state status. Species are assigned numeric ranks ranging from 1 to 5, reflecting the relative degree to which they are "at-risk". Rank definitions are given below. A number of factors are considered in assigning ranks - the number, size and distribution of known "occurrences" or populations, population trends (if known), habitat sensitivity, and threat. Factors in a species' life history that make it especially vulnerable are also considered (e.g., dependence on a specific pollinator).

GLOBAL RANK DEFINITIONS (NatureServe 2003)

G1 Critically imperiled because of extreme rarity and/or other factors making it highly vulnerable to extinction

G2 Imperiled because of rarity and/or other factors making it vulnerable to extinction

G3 Vulnerable because of rarity or restricted range and/or other factors, even though it may be abundant at some of its locations

G4 Apparently secure, though it may be quite rare in parts of its range, especially at the periphery

G5 Demonstrably secure, though it may be quite rare in parts of its range, especially at the periphery

T1-5 Infraspecific Taxon (trinomial) - The status of infraspecific taxa (subspecies or varieties) are indicated by a "T-rank" following the species' global rank

\section{STATE RANK DEFINITIONS}

S1 At high risk because of extremely limited and potentially declining numbers, extent and/or habitat, making it highly vulnerable to extirpation in the state

S2 At risk because of very limited and potentially declining numbers, extent and/or habitat, making it vulnerable to extirpation in the state

S3 Potentially at risk because of limited and potentially declining numbers, extent and/or habitat, even though it may be abundant in some areas

S4 Uncommon but not rare (although it may be rare in parts of its range), and usually widespread. Apparently not vulnerable in most of its range, but possibly cause for long-term concern

S5 Common, widespread, and abundant (although it may be rare in parts of its range). Not vulnerable in most of its range

\section{COMBINATION RANKS}

G\#G\# or S\#S\# Range Rank-A numeric range rank (e.g., G2G3) used to indicate uncertainty about the exact status of a taxon

\section{QUALIFIERS}

NR

Not ranked

Q Questionable taxonomy that may reduce conservation priority-

Distinctiveness of this entity as a taxon at the current level is questionable; resolution of this uncertainty may result in change from a species to a subspecies or hybrid, or inclusion of this taxon in another taxon, with the resulting taxon having a lower-priority (numerically higher) conservation status rank 
$\mathrm{X}$

$\mathrm{H}$

$\mathrm{U}$

HYB

?

$\mathrm{C}$

A

Z

$\mathrm{P}$

$\mathrm{R}$

SYN

$*$

B

$\mathrm{N}$

Presumed Extinct-Species believed to be extinct throughout its range. Not located despite intensive searches of historical sites and other appropriate habitat, and virtually no likelihood that it will be rediscovered

Possibly Extinct-Species known from only historical occurrences, but may never-theless still be extant; further searching needed

Unrankable - Species currently unrankable due to lack of information or due to substantially conflicting information about status or trends

Hybrid-Entity not ranked because it represents an interspecific hybrid and not a species

Inexact Numeric Rank-Denotes inexact numeric rank

Captive or Cultivated Only-Species at present is extant only in captivity or cultivation, or as a reintroduced population not yet established

Accidental-Species is accidental or casual in Montana, in other words, infrequent and outside usual range. Includes species (usually birds or butterflies) recorded once or only a few times at a location. A few of these species may have bred on the one or two occasions they were recorded

Zero Occurrences-Species is present but lacking practical conservation concern in Montana because there are no definable occurrences, although the taxon is native and appears regularly in Montana

Potential—Potential that species occurs in Montana but no extant or historic occurrences are accepted

Reported-Species reported in Montana but without a basis for either accepting or rejecting the report, or the report not yet reviewed locally. Some of these are very recent discoveries for which the program has not yet received first-hand information; others are old, obscure reports

Synonym - Species reported as occurring in Montana, but the Montana Natural Heritage Program does not recognize the taxon; therefore the species is not assigned a rank

A rank has been assigned and is under review. Contact the Montana Natural Heritage Program for assigned rank

Breeding-Rank refers to the breeding population of the species in Montana Nonbreeding - Rank refers to the non-breeding population of the species in Montana 
APPENDIX B. ELEMENT OCCURRENCE RANK DEFINITIONS 


\section{ELEMENT OCCURRENCE RANK DEFINITIONS}

A - Excellent estimated viability/ecological integrity

A? - Possibly excellent estimated viability/ecological integrity

$\mathrm{AB}$ - Excellent or good estimated viability/ecological integrity

AC - Excellent, good, or fair estimated viability/ecological integrity

B - Good estimated viability/ecological integrity

B? - Possibly good estimated viability/ecological integrity

BC - Good or fair estimated viability/ecological integrity

BD - Good, fair, or poor estimated viability/ecological integrity

C - Fair estimated viability/ecological integrity

C? - Possibly fair estimated viability/ecological integrity

CD - Fair or poor estimated viability/ecological integrity

D - Poor estimated viability/ecological integrity

D? - Possibly poor estimated viability/ecological integrity

E - Verified extant (viability/ecological integrity not assessed)

F - Failed to find

F? - Possibly failed to find

$\mathrm{H}$ - Historical

H? - Possibly historical

$X$ - Extirpated

$\mathrm{X}$ ? - Possibly extirpated

U - Unrankable

NR - Not ranked 